\title{
Lessons Learned from Recent Earthquakes - Geoscience and Geotechnical Perspectives
}

\author{
Robert C. Lo ${ }^{1}$ and Yumei Wang 2 \\ ${ }^{1}$ Klohn Crippen Berger Ltd., Vancouver, B.C. \\ ${ }^{2}$ Sustainable Living Solutions LLC, Portland, Oregon \\ ${ }^{1}$ Canada \\ 2U.S.A.
}

\section{Introduction}

Earthquakes have been occurring long before human development, and will continue to occur with or without human civilization. Nature's forces behind earthquakes are powerful, unstoppable and can be deadly. Recent earthquakes illustrate these destructive forces across the globe. In Japan's March 2011 disaster, nearly 24,000 persons perished or missing in the world's most seismically prepared country with advanced early warning systems for tsunami and earthquake. In January 2010 at Haiti, a developing nation, even worse devastation occurred with about a quarter million fatalities.

Earthquake disasters are often covered in the news media for a short time period. However, after the media blitz fizzles out, the recovery period ensues. Recovery can involve extreme socio-economic hardship - painful emotional losses, physical injuries, public health crisis, widespread environmental contamination and loss of homes and businesses. This readjustment could last for many years. With today's increasing population and economical development in seismic hazard zones (in both developing and developed nations), the global seismic risk is also going up. The field of earthquake science has seen many recent advances, some involving geoscience and geotechnical issues. Synthesized in this chapter are key advances gleaned from literature that can be applied towards risk management decisions to reduce future loss of lives and socio-economic disruptions.

As members of the Earthquake Investigation Committee (EIC) of ASCE Technical Council on Lifelines Earthquake Engineering (TCLEE), the authors have been involved in the investigation for four (Sumatra, Wenchuan, Maule and Tohoku-Oki) of the six recent earthquakes covered in this chapter, focusing on the geoscience and geotechnical aspects. This chapter first highlights the characteristics and damages of these earthquakes: the 2004/2005 Sumatra, Indonesia, 2008 Wenchuan, China, 2010 Haiti, 2010 Maule, Chile, 2010/2011 Christchurch, New Zealand, and 2011 Tohoku-Oki (East Japan) earthquakes (see Table 1). It then discusses some of the geoscience and geotechnical aspects of these earthquakes with references to other relevant seismic events. Finally, it outlines the lessons learned from these events in general as well as with respect to lifelines facilities, and draws some conclusions. 


\section{Recent earthquakes}

\subsection{General}

Table 1 summarizes the characteristics and damages of the six recent events. It provides a thumb-nail sketch of these events including: date and location, earthquake type and focal mechanism, peak ground acceleration and Modified Mercalli Intensity, special features, casualties, damages and general references. Three of these are tsunami-generating subduction events of magnitude, Mw 8.8 to 9.1-9.3 (see Fig. 1), while the other three are crustal events of magnitude, Mw 6.0 to 7.9, involving blind thrust, strike-slip/thrust or reverse faults. Prominent features of these events are briefly outlined below.

\subsection{Prominent features}

\subsubsection{4 (Mw 9.1-9.3)/2005 (Mw 8.6) Sumatra, Indonesia earthquakes/tsunamis}

The December 26, 2004 Sumatra earthquake was triggered by the rupture of a locked segment of the fault plane at least $500 \mathrm{~km}$ long by $150 \mathrm{~km}$ wide between the subducting Indo-Australian Plate and the upper Eurasian (Burma) Plate (see Fig. 2). Figure 3 shows the computed vertical and horizontal components of surface displacements of the upper plate based on a finite-fault model (EERI 2005, 2006, ASCE 2007, BSSA 2007).

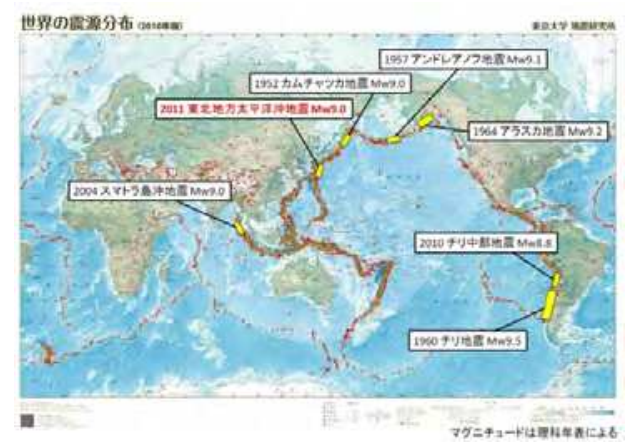

Fig. 1. Major Circum-Pacific Subduction Earthquakes Since 1957. http:/ / outreach.eri.utokyo.ac.jp/ eqvolc/201103_tohoku/

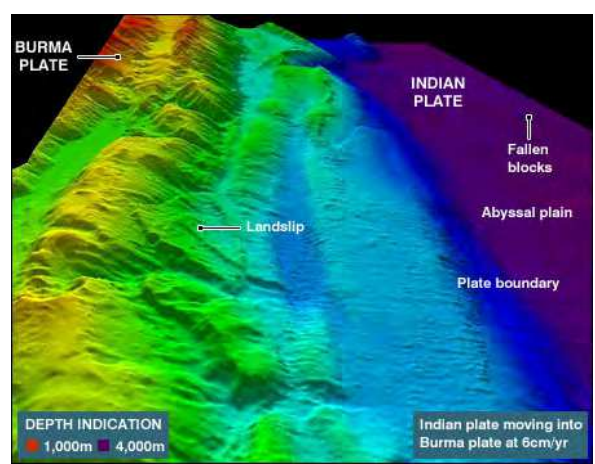

Fig. 2. Three-Dimensional Sonar Imagery of Seabed off the coast of Sumatra Island. (BBC 2005) 


\begin{tabular}{|c|c|c|c|c|}
\hline 芠 & 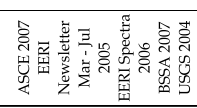 & 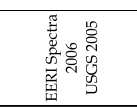 & 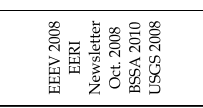 & 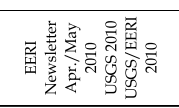 \\
\hline 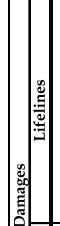 & 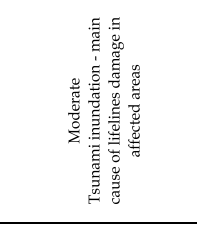 & 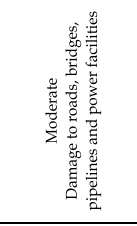 & 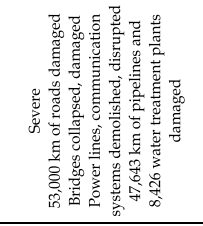 & 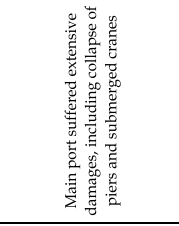 \\
\hline ن & 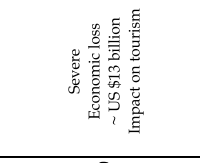 & 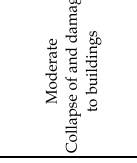 & 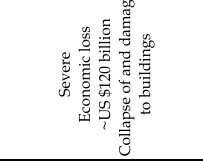 & 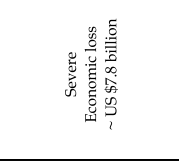 \\
\hline & 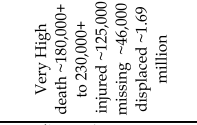 & 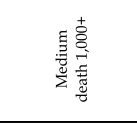 & 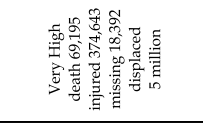 & 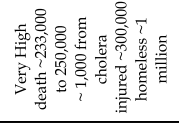 \\
\hline & 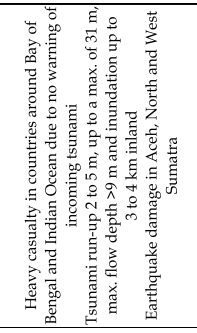 & 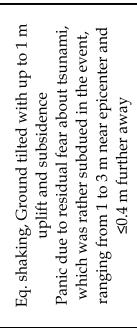 & 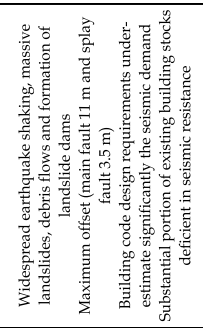 & 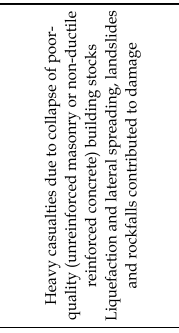 \\
\hline 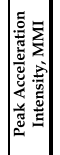 & 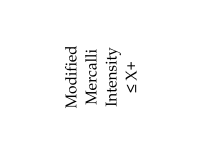 & 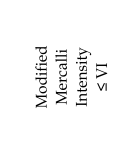 & 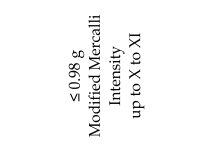 & 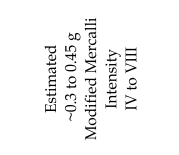 \\
\hline & 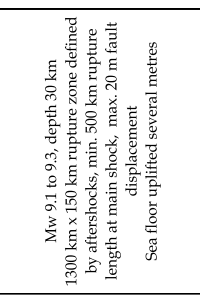 & 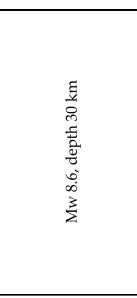 & 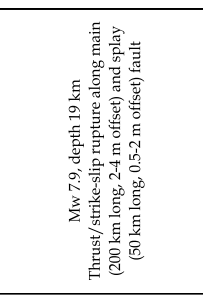 & 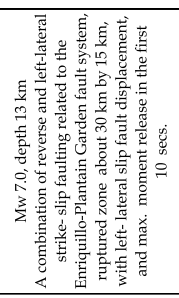 \\
\hline g. & 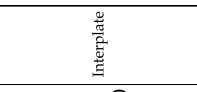 & 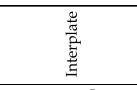 & 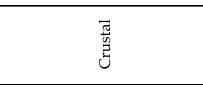 & 普 \\
\hline 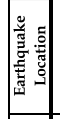 & 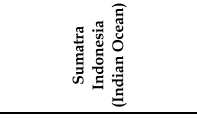 & 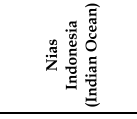 & 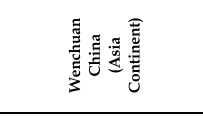 & 高 \\
\hline \begin{tabular}{|c|c|} 
\\
\end{tabular} & 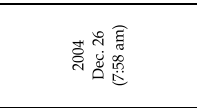 & 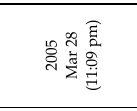 & 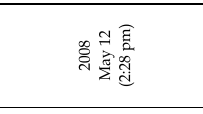 & 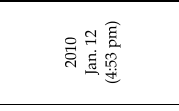 \\
\hline
\end{tabular}

Table 1. Summary of Relevant Earthquake and Damage Data for Six Recent Earthquakes In 2004 to 2011 


\begin{tabular}{|c|c|c|c|c|}
\hline 资 & 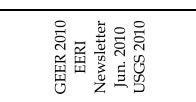 & 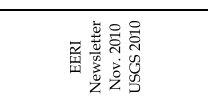 & 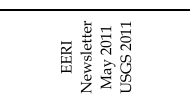 & 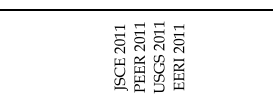 \\
\hline . & 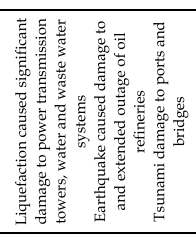 & 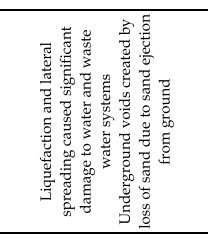 & 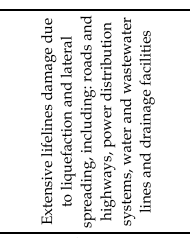 & 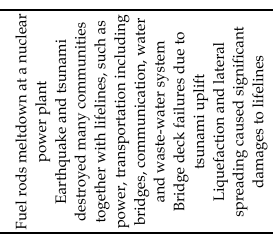 \\
\hline 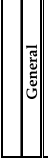 & 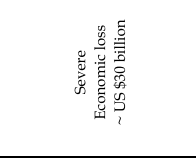 & 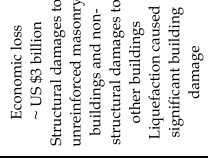 & 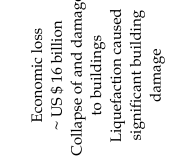 & 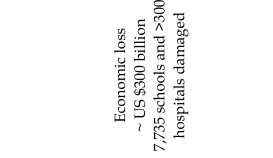 \\
\hline 递 & 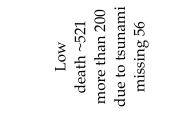 & 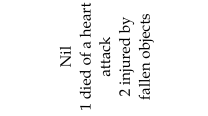 & 疍 & 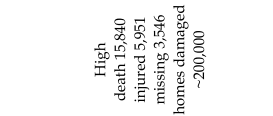 \\
\hline 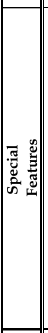 & 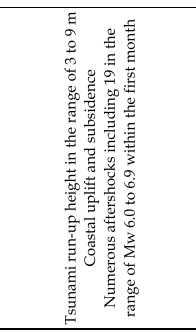 & 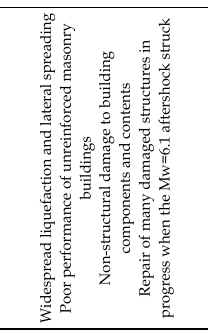 & 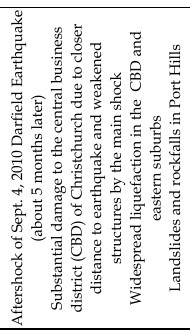 & 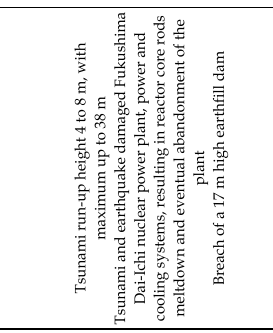 \\
\hline 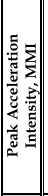 & 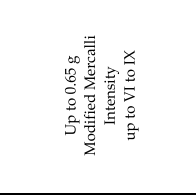 & 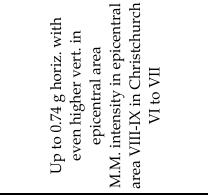 & 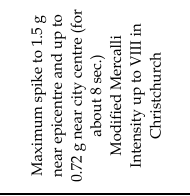 & 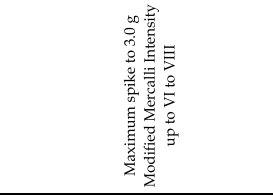 \\
\hline 量 & 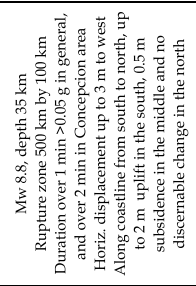 & 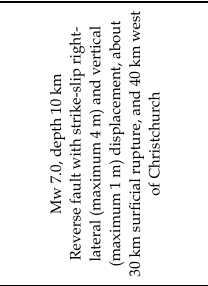 & 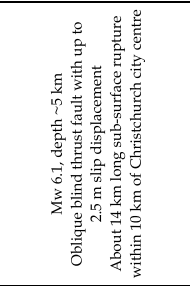 & 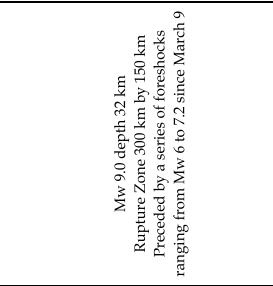 \\
\hline 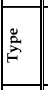 & 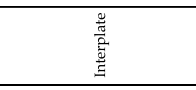 & 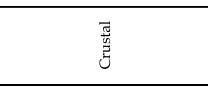 & 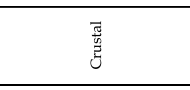 & 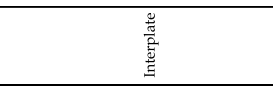 \\
\hline 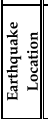 & 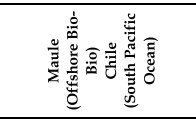 & 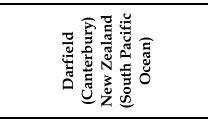 & 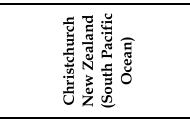 & 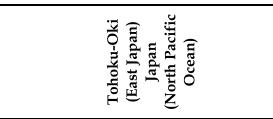 \\
\hline 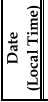 & 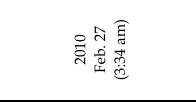 & 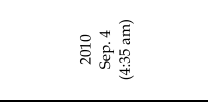 & 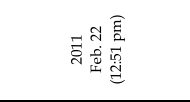 & 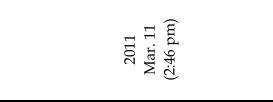 \\
\hline
\end{tabular}

Table 1. (continued). Summary of Relevant Earthquake and Damage Data for Six Recent Earthquakes In 2004 to 2011 
The stealthy nature of tsunami onslaught of coastal inhabitants and international tourists around the Bay of Bengal and Indian Ocean (see Fig. 4) in the morning after Christmas of 2004 and ensuing heavy casualty focused the world's attention at the time. The tsunami runup height had considerable variation around the Indian Ocean, but ranged in general from 2 to $5 \mathrm{~m}$, and reaching a maximum of $31 \mathrm{~m}$ in Sumatra (see Fig. 5). The event served as an impetus to improve the tsunami-warning system for the countries in the region. Although the subsequent smaller event on March 28, 2005 further south involved nominal tsunami waves reaching 1 to $3 \mathrm{~m}$ height locally and did far less damage, it stirred up considerable local fear due to the dreadful earlier event.

No strong-motion acceleration time histories were recorded in the epicentral region. In the near-field northwest and north Sumatra, tsunami compounded earthquake-shaking damage. In the far-field tsunami was the predominant cause of destruction. The severity of tsunami damage was affected by many factors such as bathymetry, shoreline configuration and topography, etc. which influenced the wave focusing, reflection and refraction; tsunami run-up height; extent of inland inundation; flow velocity and scour, wave pressure, uplift and debris impact force. EERI (2006) noted the following tsunami-related phenomena:

- Maldives suffered moderate damage, although the coral-atolls archipelago rises only about $2 \mathrm{~m}$ above the mean sea level. Since the islands rise from the seafloor steeply, wave amplification was nominal.

- The Indian mid-ocean ridges served as wave guides, and funnelled the tsunami away from the tip of Africa.

- The tsunami generating capacity of an earthquake is governed by the mass of the water body suddenly displaced by the seafloor movement. The presence of the Nias and Simeulue Islands reduced the affected water body during the 2005 earthquake, thus induced relatively low tsunami.

- Unlike tidal gauges that could be affected by harbour resonance, tsunameters can indicate free-field tsunami height.
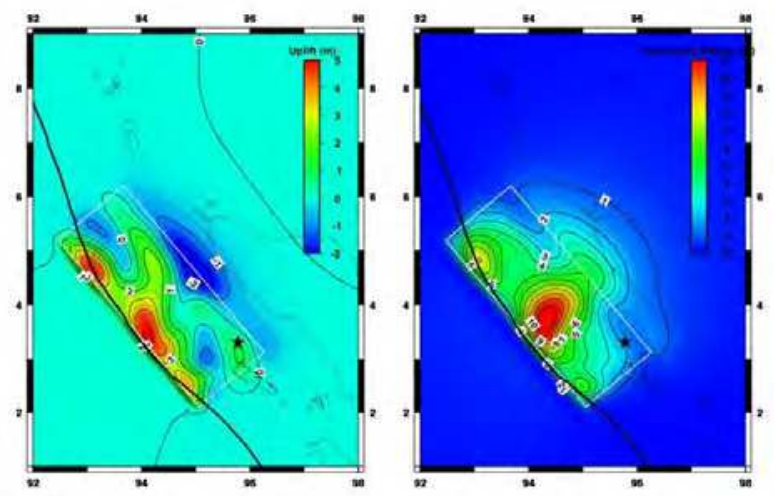

Fig. 3. Modelled Surface Displacements of the Upper Plate in Metres, for Vertical (Left) and Horizontal (Right) Components, 2004. http:/ / neic.usgs.gov/neis/eq_depot/2004/ eq_041226/neic_slav_ff.html 


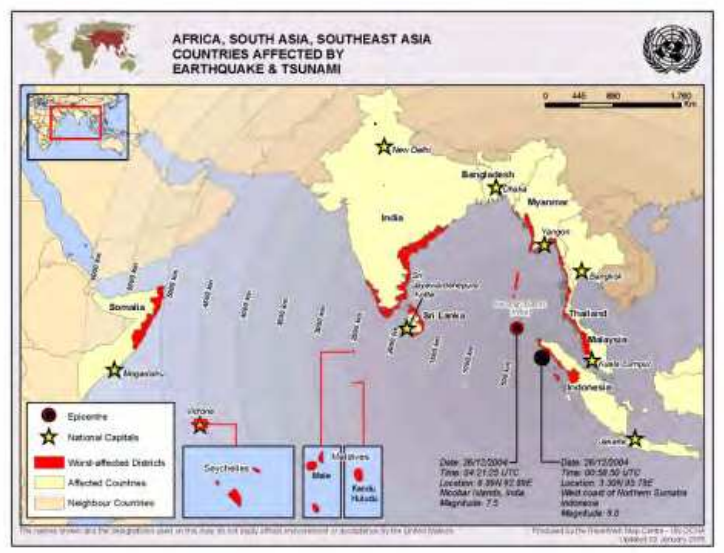

Fig. 4. Tsunami-Damaged Countries Around Indian Ocean, 2004.

(UN OCHA 2005)

- Two types of leading waves of tsunami were modelled back in 1994: a leading depression $\mathrm{N}$-wave (LDN) and a leading elevation $\mathrm{N}$-wave (LEN). Tide-gauge records on Fig. 6 confirmed the validity of the earlier hydrodynamic modelling: LDN wave was shown on Phuket, Thailand record, while LEN wave on Male, Maldives record. Historically, the leading depression $\mathrm{N}$-wave, i.e., that causing the initial receding of the shoreline as the tsunami approaching, has been a death trap for many unwary fishermen and beachcombers.

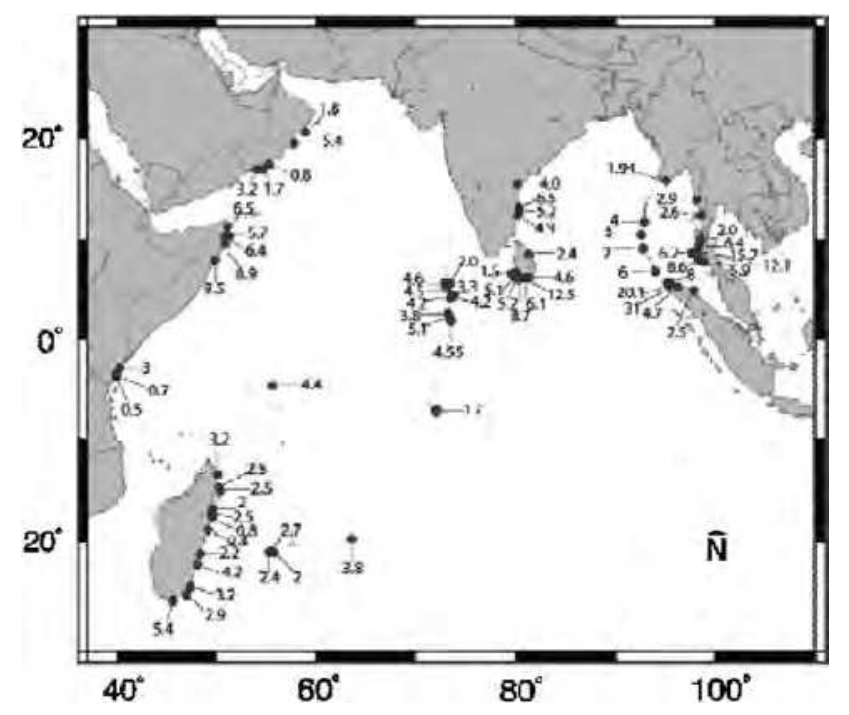

Fig. 5. Representative Tsunami Runup Heights along Shores of Indian Ocean, 2004. (EERI 2006) 


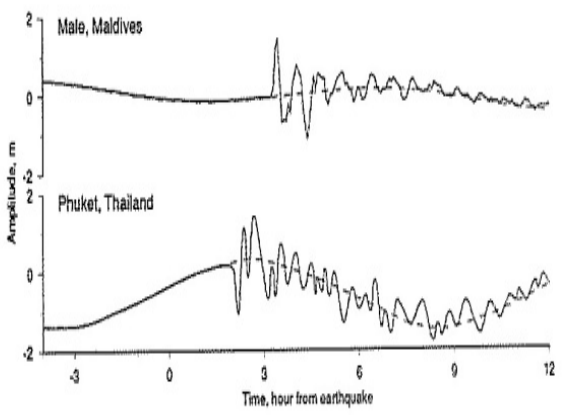

Fig. 6. Tide Gauge Records from Male, Maldives and Phuket, Thailand, 2004. (EERI 2006)

\subsubsection{8 (Mw 7.9) Wenchuan, China earthquake}

The latent threat of the causative Longmenshan fault system was formally recognized by the geoscience research community about a year prior to the 2008 event, but this finding did not influence the seismic code at the time. The major seismic event of Mw 7.9 impacted a large region in the southwest China, involving several provinces that were significantly underdesigned for the event. Figures 7 and 8 show the conditions of the old Beichuan town before and after the earthquake.

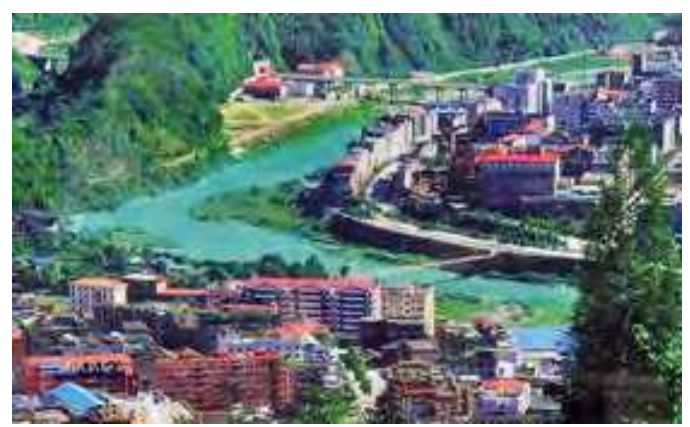

Fig. 7. Old Beichuan Town Before Earthquake. http://www.eeri.org/site/meetings/uschina-us-china-symposium

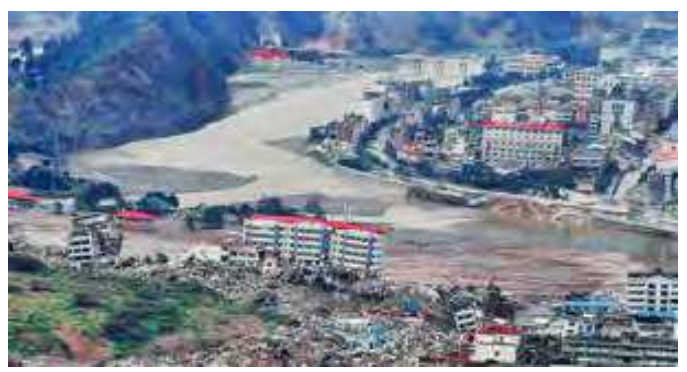

Fig. 8. Old Beichuan Town After Earthquake. http://www.eeri.org/site/meetings/uschina-us-china-symposium 
Due to the steep and rugged topography in the affected mountainous region, wide spread landslides (see Figs. 9 and 10) have been major destructing factors, besides strong earthquake shaking (EEEV 2008, EERI 2008). About 20,000 fatalities, near one-fourth of the total, were caused by 15,000 geohazards in the form of landslides, debris flows and rockfalls, with the largest landslide involving a volume of 1.1 billion $\mathrm{m}^{3}$. In the high, steep slopes (see Fig. 10) along the $270 \mathrm{~km}$ long Longmenshan tectonic belt, the large vertical acceleration and topographic amplification of ground motion have resulted in more than 10,000 potential geohazard sites after the event (Yin et al. 2011).

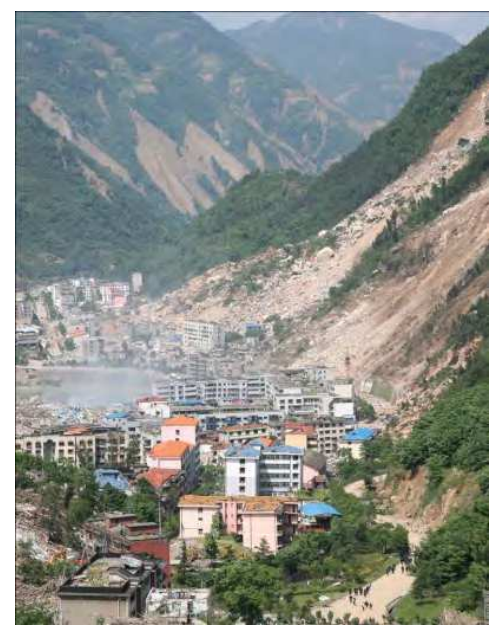

Fig. 9. Landslides in Proximity of Old Beichuan Town. http://www.agu.org/news

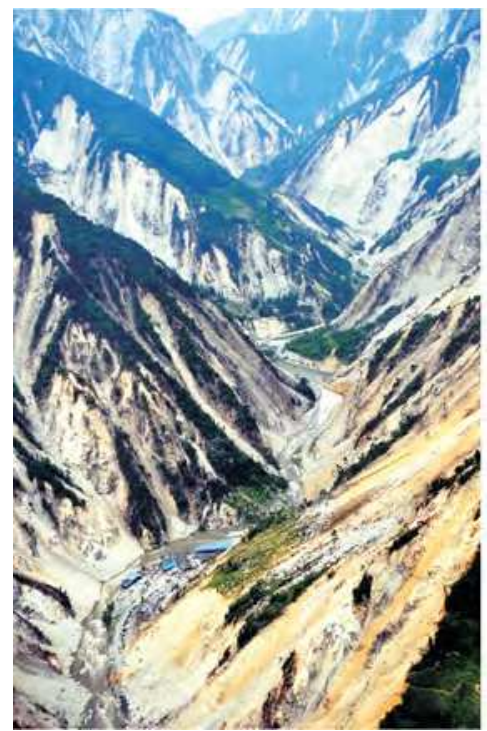

Fig. 10. Landslides along Minjiang River near Wenchuan County. (EEEV 2008) 
Up to 34 landslide lakes were formed in Sichuan and one in Gansu provinces, threatening about 700,000 people living downstream. The largest one was located in Tangjiashan, Beichuan County (see Fig. 11), with a 71-m high debris dam blocking the Shitingjian river forming a lake about $800 \mathrm{~m}$ long and $600 \mathrm{~m}$ wide. The downstream flood-threatened area had to be evacuated, and the debris dam breached by excavation and blasting to remove the secondary flood hazard.

Figure 12 shows the number and severity of landslides per $\mathrm{km}$ of National Highway Route \#213 over the hanging wall versus foot wall. As expected in a thrust-fault earthquake (Sommerville 2000), there is substantially more damage over the hanging wall as compared to that over the foot wall. Similarly, there is more damage in the area along the earthquake propagation direction than in the opposite direction.

The strong shaking with peak ground acceleration up to $0.98 \mathrm{~g}$, ground failures and fault displacements up to 2 to $4 \mathrm{~m}$ caused wide spread destruction of communities and infrastructures. The long duration of strong shaking, over 100 seconds in general, was detrimental to unreinforced masonry buildings, and non-ductile reinforced concrete buildings that form the bulk of the building stock in the affected area. Figure 13 shows the acceleration response spectra at Qingping Station in the epicentral region (Ventura et al. 2008). Superimposed on the figure is the design acceleration spectra for Vancouver, British Columbia with Site Class C local soil condition, according to NBCC (2005) code for comparison purposes. As typical in most earthquakes, vertical peak ground acceleration is of similar value as its horizontal counterparts in the near field.

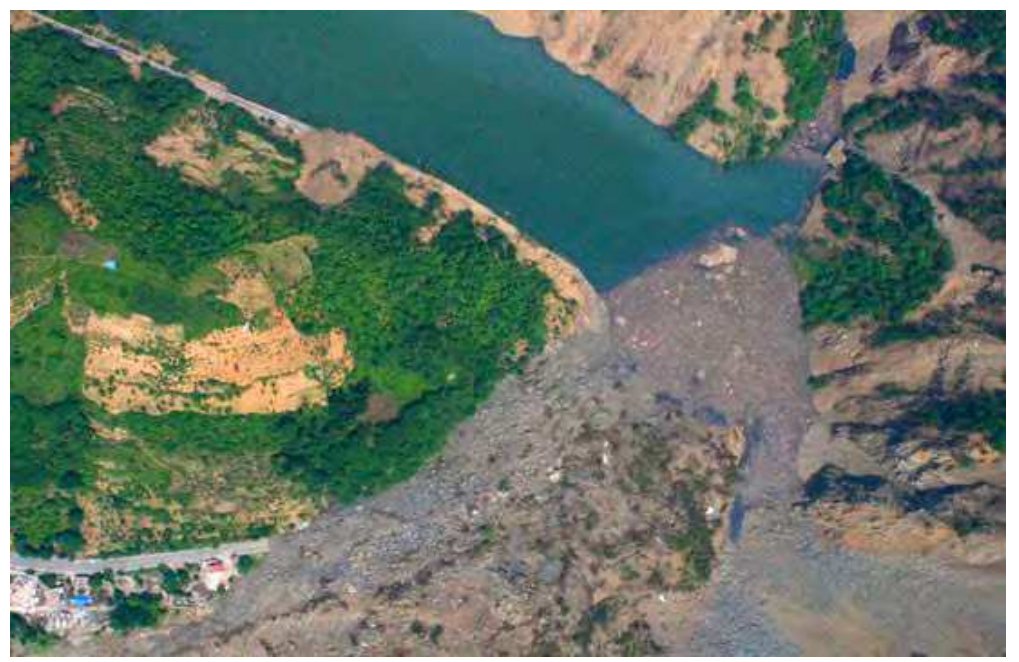

Fig. 11. Landslide Lake at Tangjiashan Landslide. Engineering Resilient Cities - Mahin - Oct 2008

Initially, accesses to remote areas were handicapped by the disruptions of highways and railways. The prompt and orderly nation-wide rescue and restoration programs were responsible for mitigating the suffering of affected population and the recovery of the region to normalcy. The unique Chinese mechanism for emergency response, recovery and 


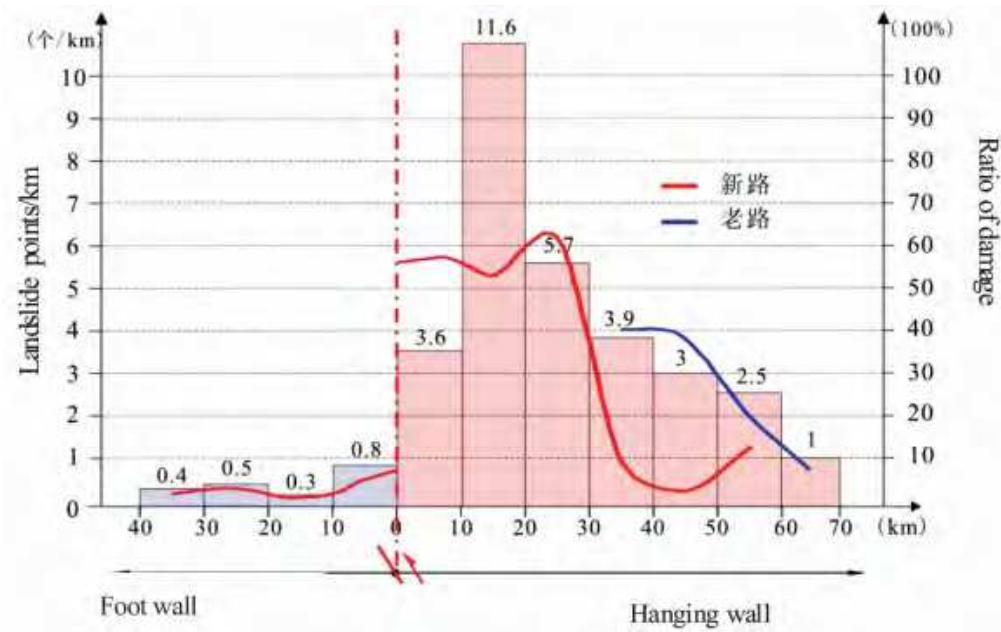

Fig. 12. Landslide Activities above Hanging Wall versus Foot Wall. (EEEV 2008).

reconstruction involved communities and jurisdictions located far away from the damaged areas. This twinning of communities in need and those to help accomplished dual goals: sharing of enormous financial hardship; and cultivating camaraderie among population. Figure 14 shows some of the officials who had spent several months in a donated school to assist relocated residents from outlying communities including the neighbouring province. Temporary dwelling units were set up across the earthquake damaged region. Figure 15 shows that the communities thus set up have become new settlements with all amenities to conduct normal life. Residents were finding work both within the settlement and outside. Grain drying activity was seen in the foreground of the figure (Lo 2009).

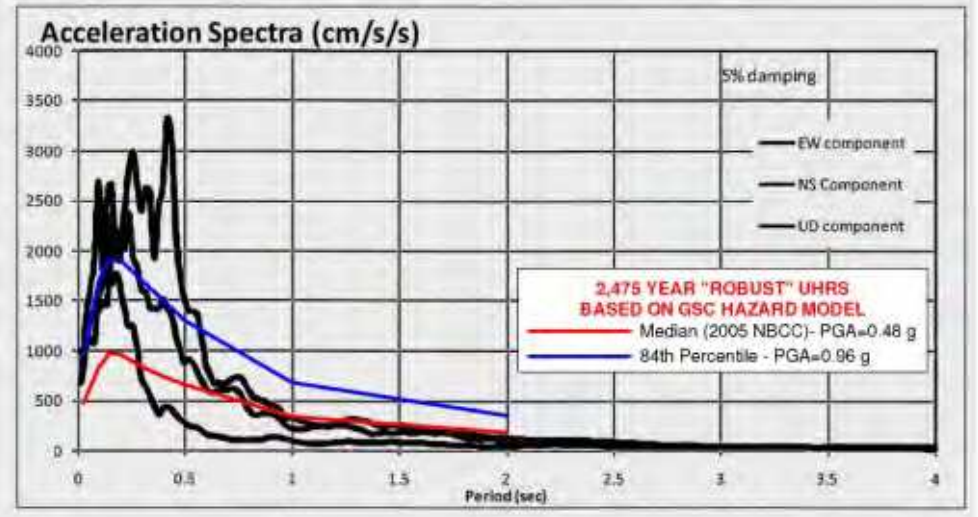

Fig. 13. Acceleration Response Spectra for Qingping Station in Epicentral Region. (Ventura et al. 2008) 


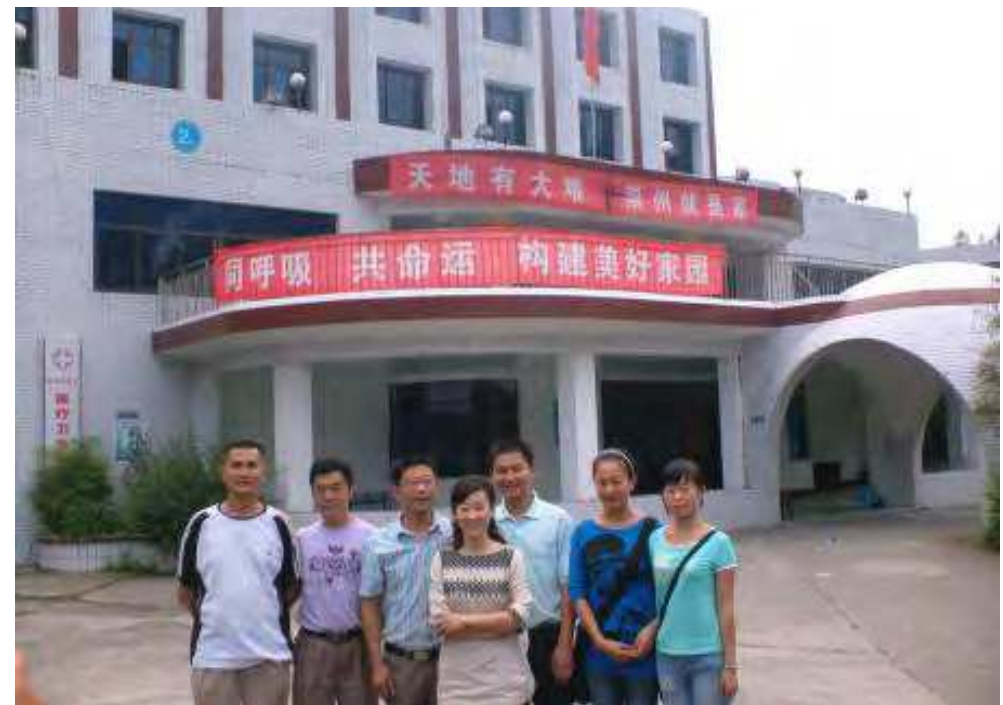

Fig. 14. School Donated for Temporary Accommodation of Survivors in Chongzhou, 2008.

A comprehensive three-year reconstruction program covered the management organization and socio-economical structure for regional revitalization, and was carried out by the twinned communities. A new Beichuan town was constructed in Yongchang City about $25 \mathrm{~km}$ downstream of the destructed town with many traditional architectural elements of the local Qiang minority (see Fig. 16).

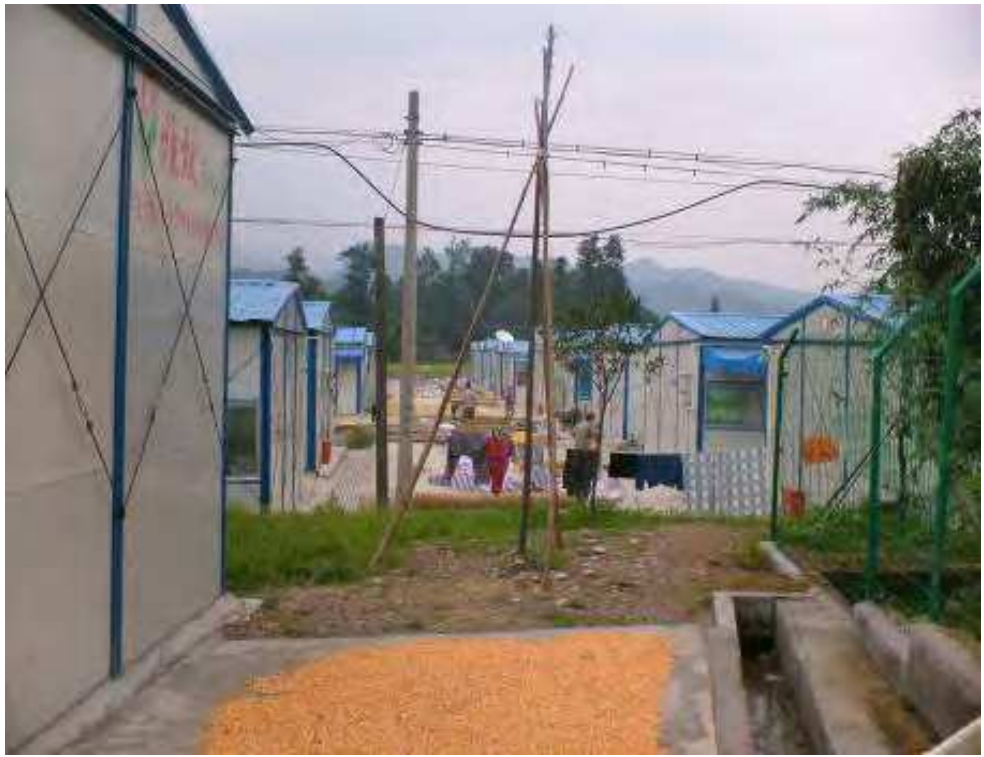

Fig. 15. Relocated Community in Temporary Accommodation of Chongzhou, 2008. 


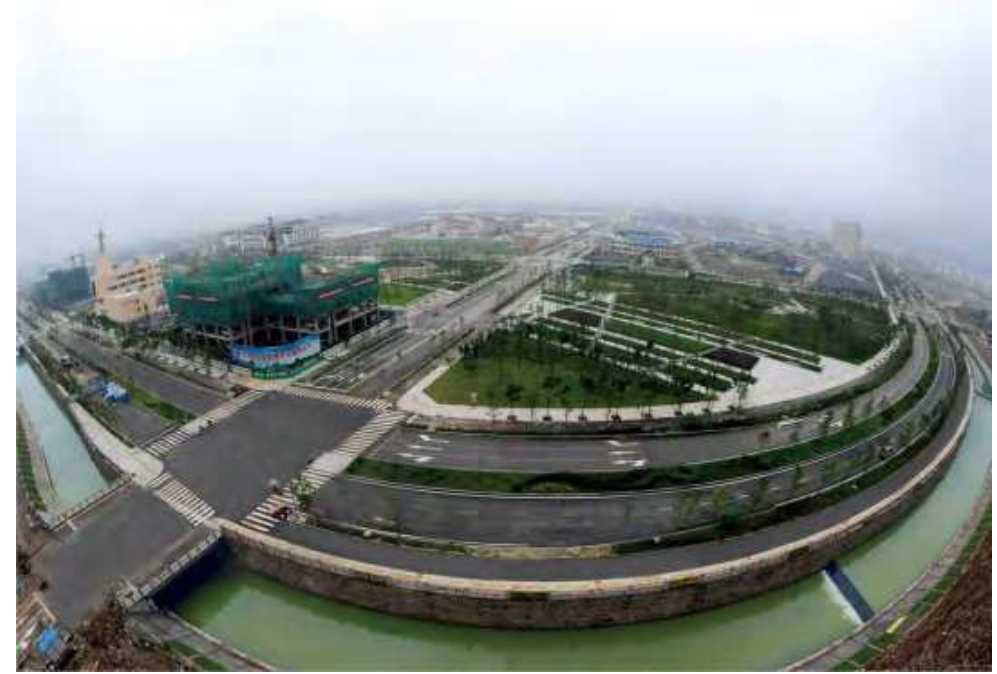

Fig. 16. City Scene Along Yongchang Boulevard, Yongchang, Sichuan - New Beichuan Town. http:/ / www.skyscrapercity.com/ showthread.php?t=1222823

Figure 17 shows the Yongchang River Bank, and Figure 18, an apartment building constructed in the new town with the support of a twinned city located near the northeast coast of China, about 1,400 km away.

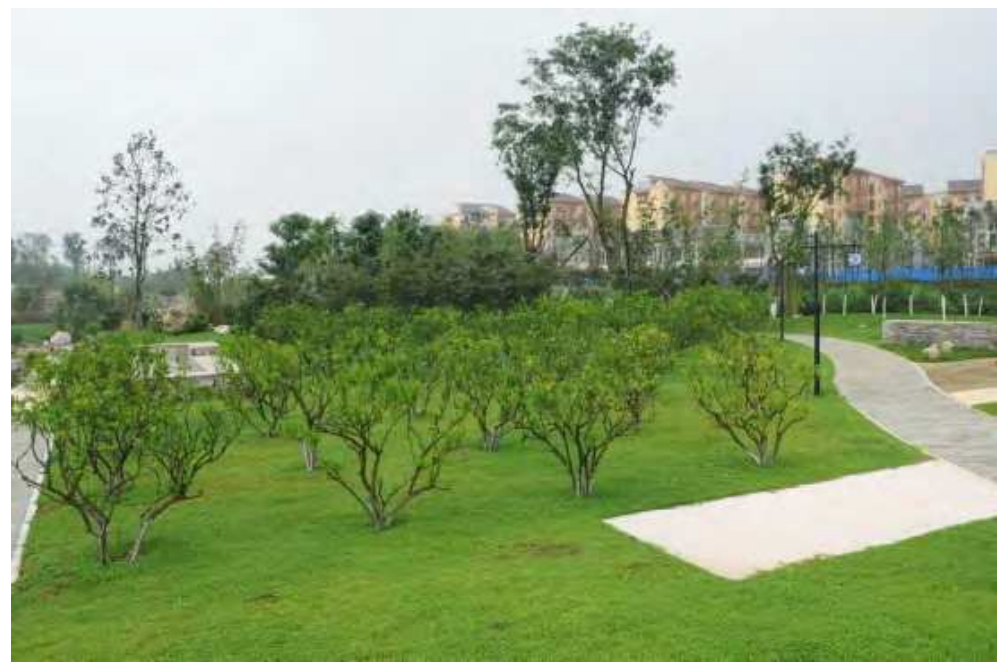

Fig. 17. Yongchang River Bank, Yongchang http://www.skyscrapercity.com/ showthread.php?t=1222823 


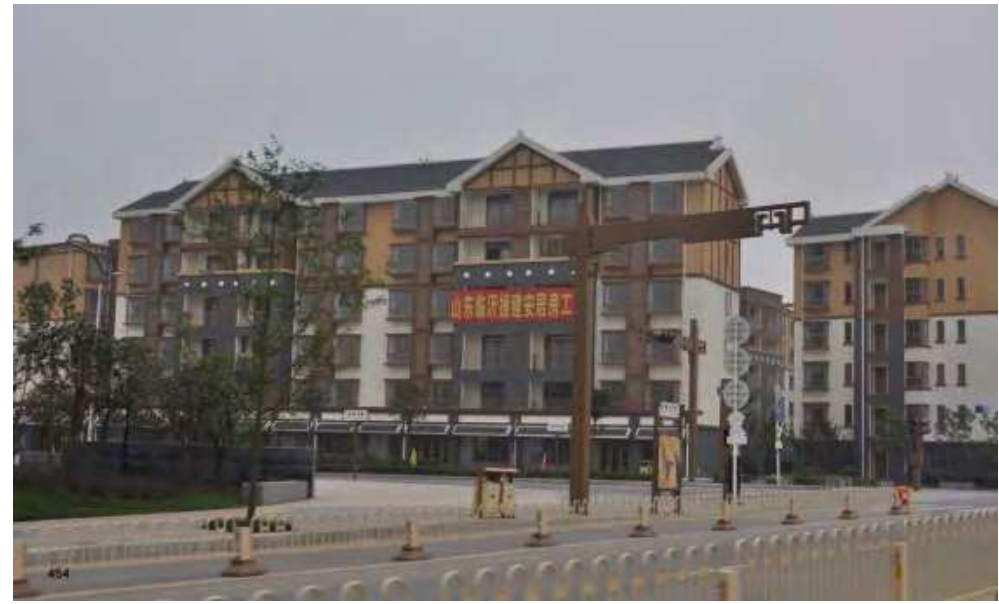

Fig. 18. New Apartment Building Constructed with Support from Linyi City, Shandong Province, 2010. http://www.eeri.org/site/meetings/ us-china-symposium

\subsubsection{0 (Mw 7) Haiti earthquake}

Haiti has suffered devastating earthquakes similar to the 2010 event in the past, despite recent seismic quiescence. The 2010 earthquake is caused by a combination of reverse and left-lateral strike-slip faulting related to the Enriquillo-Plantain Garden fault system. The threat of this specific fault to the population was not recognized prior to the event (EERI 2010, USGS/EERI 2010). There is no strong motion record for the main shock in Haiti. Peak ground acceleration was estimated in the range of 0.3 to $0.45 \mathrm{~g}$ in the affected area. The building stocks, consisting mainly of unreinforced masonry and non-ductile reinforced concrete structures (see Fig. 19) including government buildings (see Fig. 20) and buildings

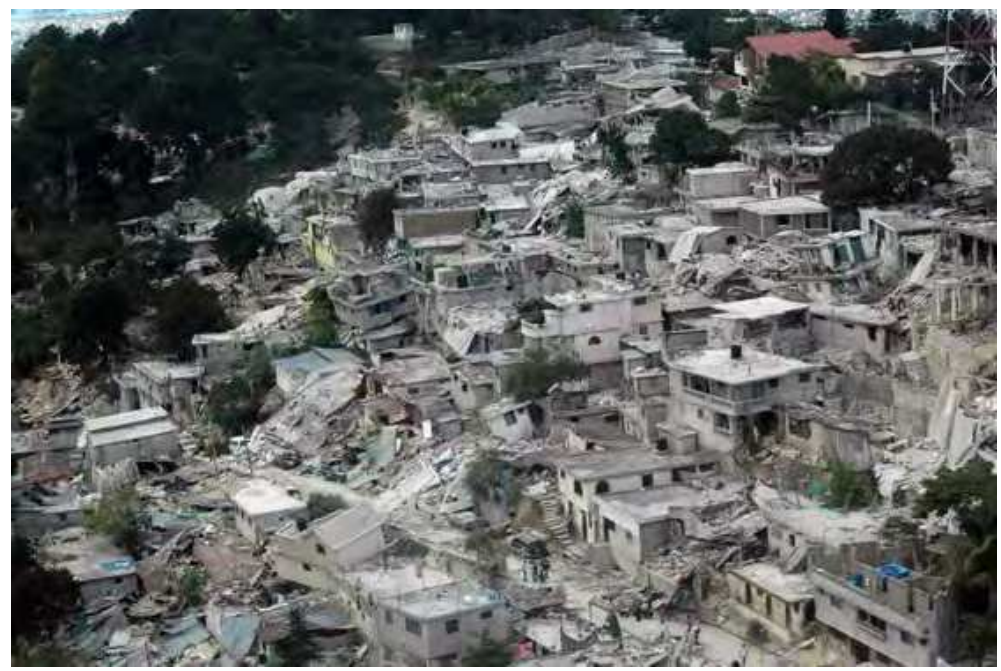

Fig. 19. Damaged Buildings Located on Hill Slope. http://www.worldcatastrophe.com 
used by the United Nation Stabilization Mission Headquarters, are generally inadequate to withstand this level of shaking (Fierro and Perry 2010). The earthquake fatality was estimated at about 233,000 to 250,000, with 300,000 injured and 1 million homeless. Subsequent to the earthquake outbreaks of cholera caused about 1,000 deaths as of October 2010 due to the poor hygiene condition.

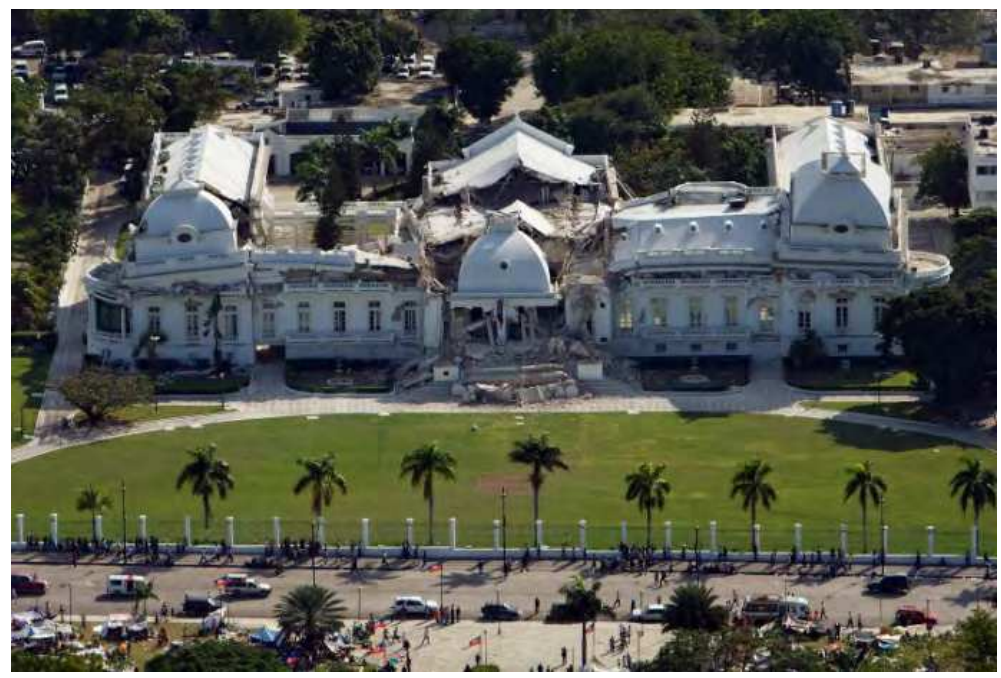

Fig. 20. Damaged Presidential Palace in Port-au-Prince. http://alanrdennis.wordpress.com

After the event, USGS (2010) developed initial seismic hazard maps for Haiti to assist the management of earthquake response and reconstruction effort. The increased seismic hazard along the adjacent portion of the Enriquillo fault directly to the south of Port-auPrince must be considered in the post-earthquake reconstruction.

\subsubsection{0 (Mw 8.8) Maule, Chile earthquake/tsunami}

In the 2010 Maule, Chile earthquake, the tsunami contributed close to half of the total casualty of about 521 due to the timing of the event occurring in the early morning. Tsunami damage to the over $500 \mathrm{~km}$ long coastline varied, as it came in during low tide and involved 3 to 4 major surges. Tsunami run-up height generally ranged from 3 to $9 \mathrm{~m}$ in the epicentral region with the maximum reaching about $20 \mathrm{~m}$ along cliff faces.

The relative low casualty speaks for the seismic-resistant capacity of the general building stocks. The fact that high-occupancy buildings were vacant at the time of earthquake also helped to reduce casualty. Damaged or collapsed buildings suffer design flaws such as lack of vertical continuity of load-bearing structural elements, relatively thin shear walls and lack of detailing requirements for reinforcing steel in special boundary elements, etc. (GEER 2010). After the earthquake, looting has been reported in the affected region until the army was deployed to maintain law and order.

Figure 21 shows the modelled slip distribution over the fault plane in the land area. The maximum fault slip along the coast line is about $300 \mathrm{~cm}$. The earthquake occurred in the 
summer with prevailing low water table. It reduced the occurrences of landslides and liquefaction. The relatively long duration of earthquake shaking did trigger slope slumps in marginally stable or wave-undermined natural slopes, and liquefaction and lateral spreading in low-lying areas with high water table. Figure 22 shows a concrete pier used for unloading fish catches from small vessels at the Coronel fishing port. Its failure appears to be caused by the combination of earthquake shaking, foundation liquefaction and possibly tsunami wave force.

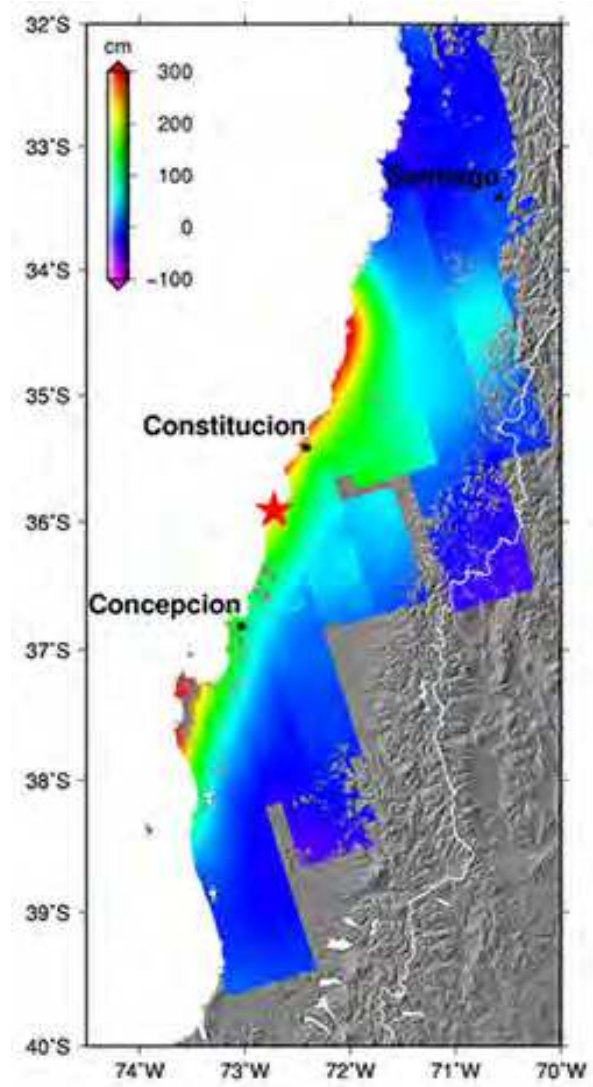

Fig. 21. Fault Plan Slip Distribution over land area - Maule, Chile. http:/ / tectonics.caltech.edu/sliphistory/2010_chile/index.html

The flow failure of a tailings dam triggered by the earthquake is shown in Figs. 23 and 24 (GEER 2010). Compared with a large number of tailings dam failures in the 1965 La Ligua earthquake and two failures in the 1985 Santiago earthquake, tailings dam performance in this event seems to show some improvement. Compacted engineering fills and structures supported by improved ground using stone columns and micro-piles were reported to perform well. 


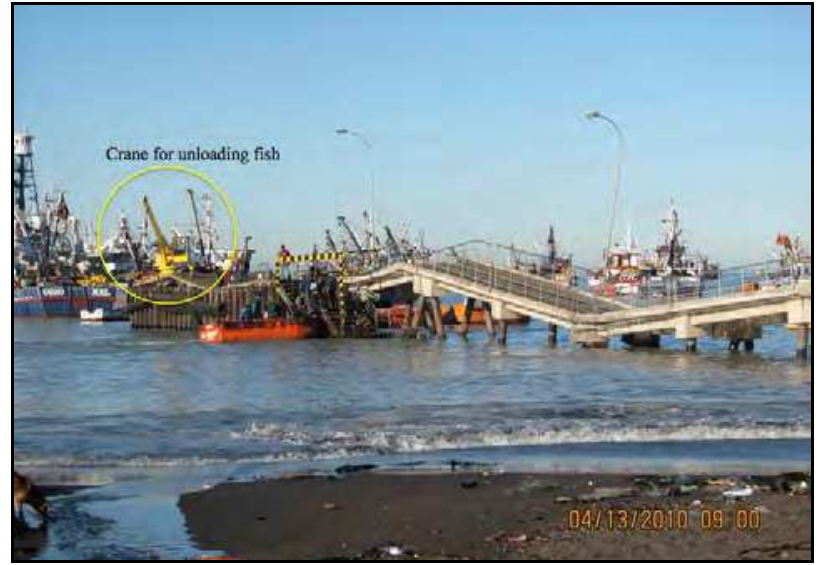

Fig. 22. Distorted Fish-Unloading Concrete Pier at Coronel Port, Chile. (TCLEE 2010)

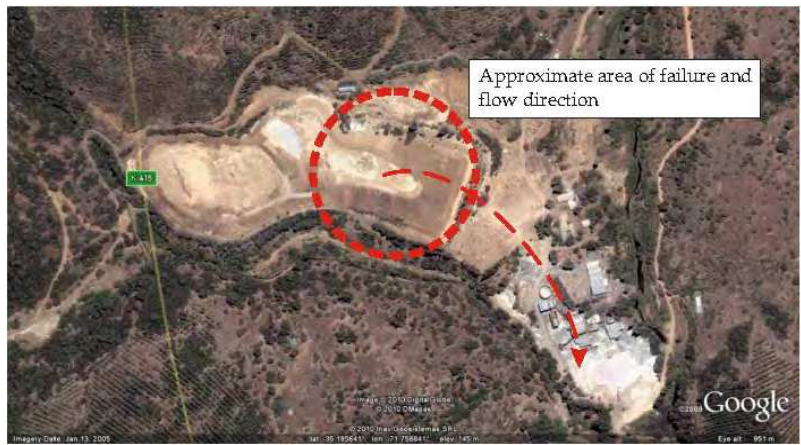

Fig. 23. Bird's-eye View of Las Palmas Tailings Impoundment Prior to Failure. (GEER 2010)

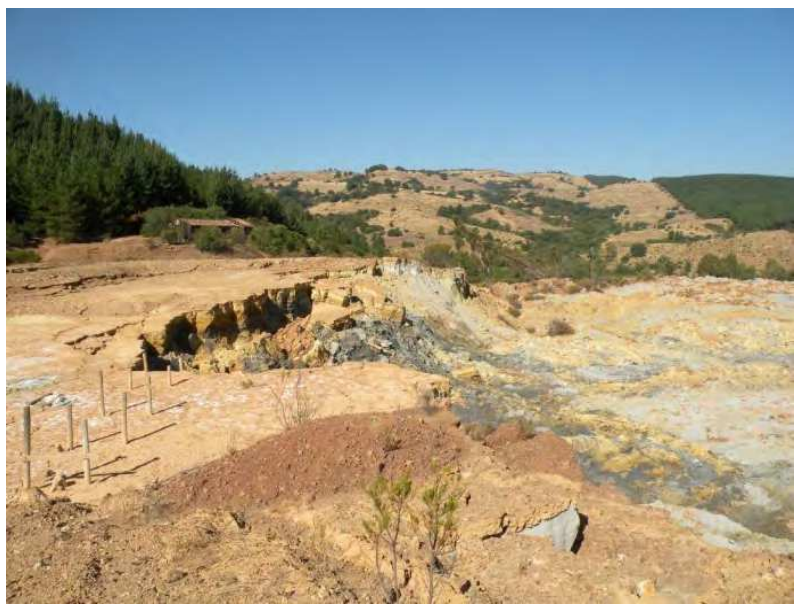

Fig. 24. Upper Scarp of Failed Tailings Impoundment. (GEER 2010) 


\subsubsection{0/2011 (Mw 7.0) Darfield (Canterbury) / (Mw 6.1) Christchurch New Zealand earthquakes}

Both the September 2010 Mw 7.0 Darfield and February 2011 Mw 6.1 events were shallow crustal earthquakes, which triggered wide-spread liquefaction in the fluvial and diluvial deposits in the epicentral region (see Figs. 25 and 26). Peak ground accelerations spiking above $1 \mathrm{~g}$, often with higher vertical than horizontal acceleration, were reported in the epicentral areas of both events. In the central business district of Christchurch, the largest city on the South Island, peak acceleration reached about $0.7 \mathrm{~g}$ on February 22, 2011 as compared to about $0.3 \mathrm{~g}$ on September 4, 2010. Figure 27 shows the horizontal acceleration response spectra for Christchurch Hospital with 5\% damping. It illustrates that the aftershock is reflected by the current New Zealand 2,500-year design spectrum, while the main shock is corresponding to the 500-year design spectrum. Proposal to increase the design spectrum for periods less than $1.5 \mathrm{sec}$ is being considered (EERI 2010/2011).

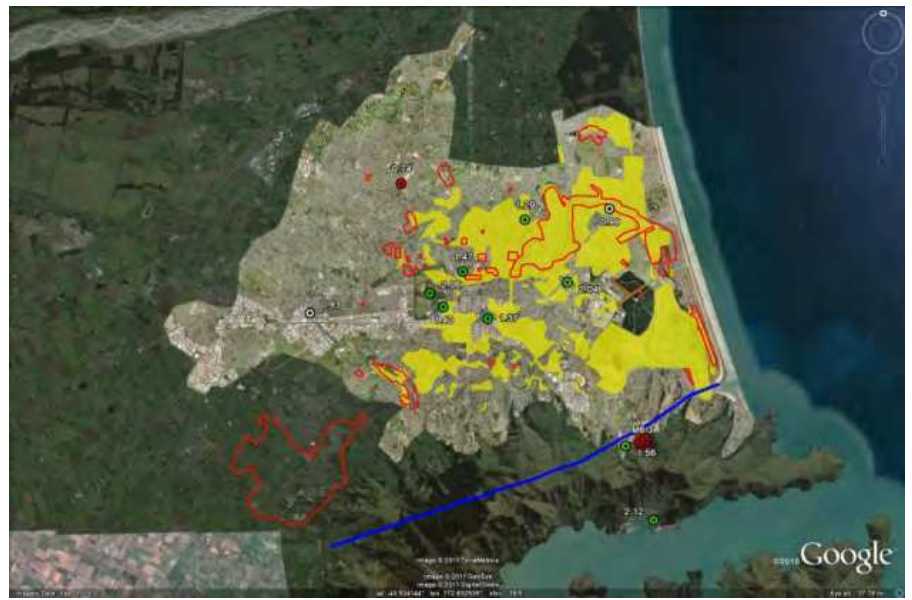

Fig. 25. Liquefaction Maps: Sept. 2010 (Red) and Feb. 2011 (Yellow). (GEER 2011)

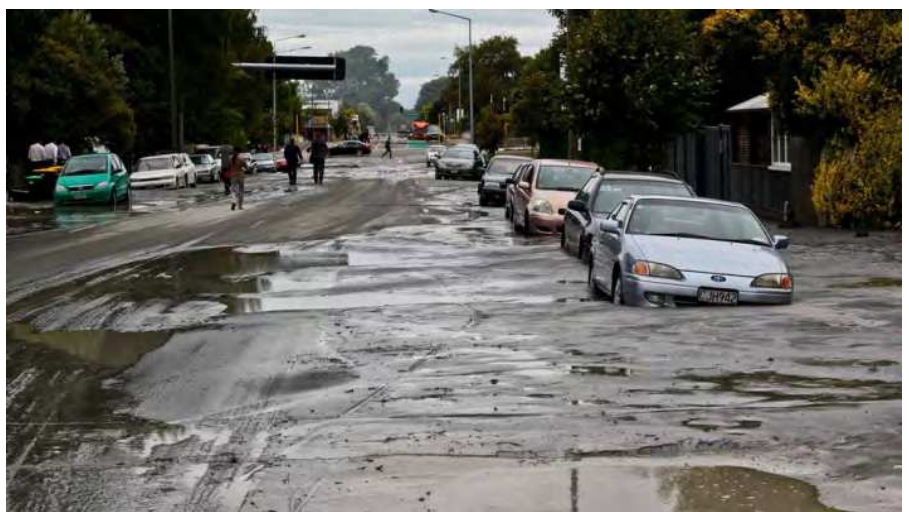

Fig. 26. Liquefied Sand Deposited on Street, 2011. http://otilya.com/view/ News/AsiaPacific/New-Zealand 
The smaller aftershock caused significant casualties and heavier structure damages in Christchurch (see Figs. 28, 29 and 30) than the main event, because it occurred much closer to the central business district, where many buildings had already suffered varying degrees of damage due to the prior event.

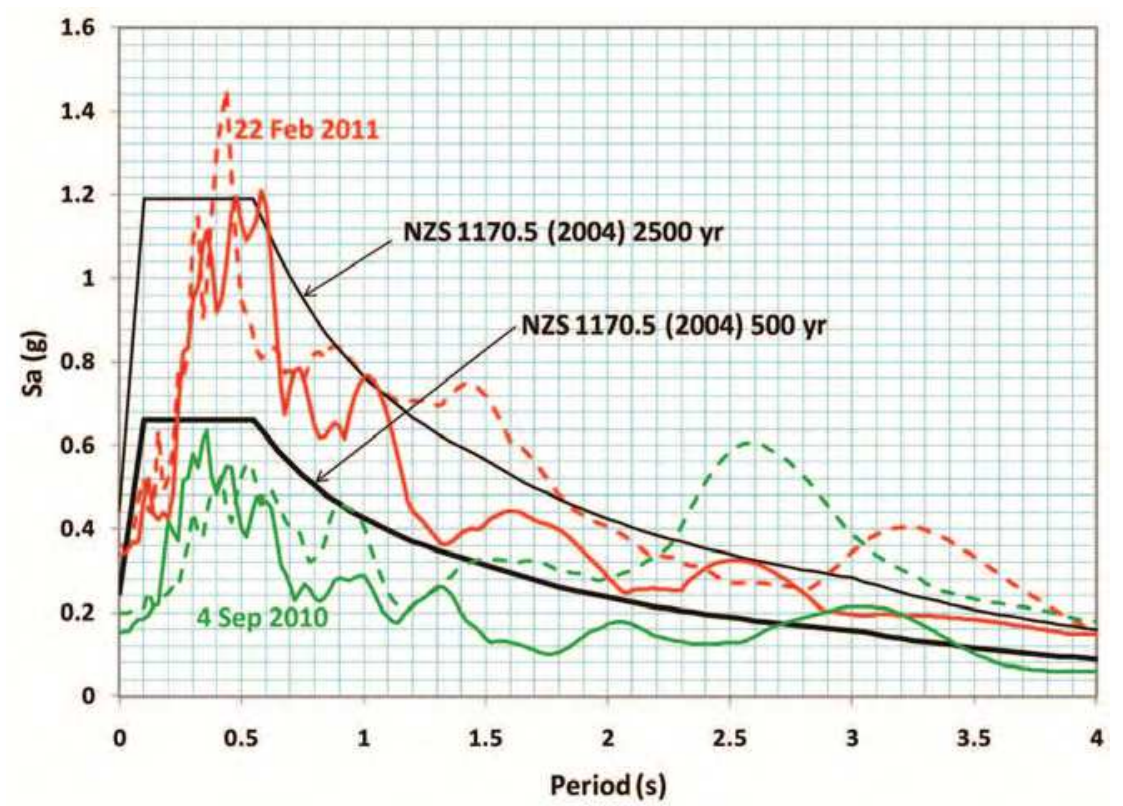

Fig. 27. Horizontal Acceleration Response Spectra for Christchurch Hospital. (EERI 2011)

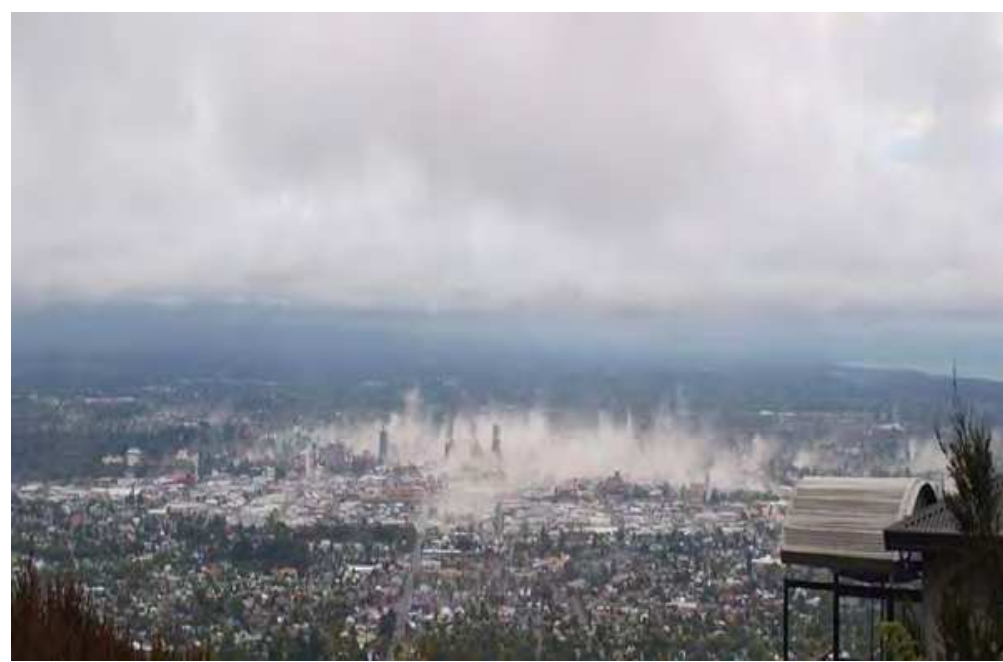

Fig. 28. Scene of Downtown Christchurch Captured by a Tourist During Earthquake, 2011. http://otilya.com/view/christchurch_as_the_quake_hits.html 
Unreinforced masonry and non-ductile reinforced concrete buildings suffered most structural damages, while liquefaction and lateral spreading contributed to foundation failures or differential settlement of buildings and pipeline breaks. Non-structural damages to building components and content caused food-supply shortage and slowed down business recovery. Other damages were caused by rock falls in the Port Hills area.

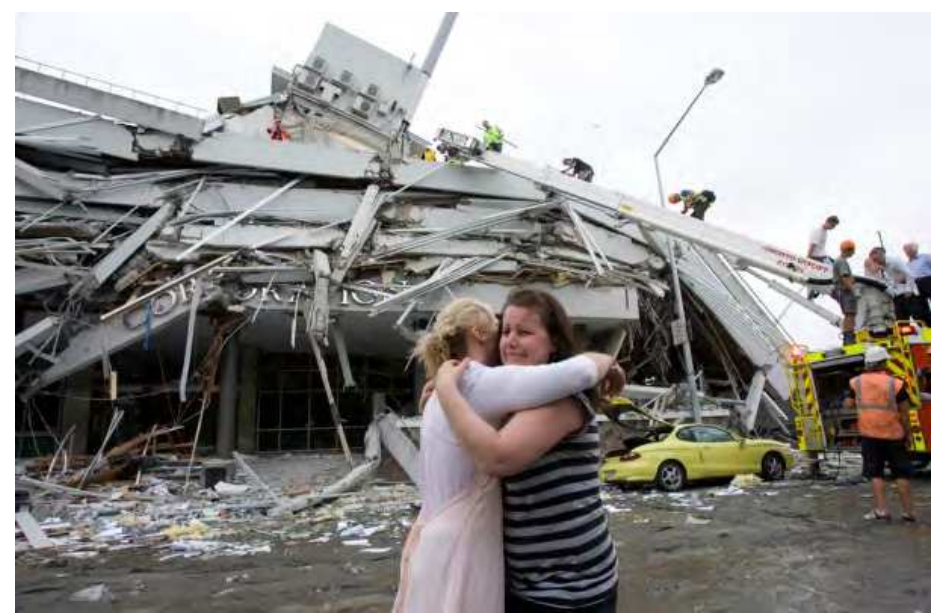

Fig. 29. Two Survivors Comforting Each Other During Rescue Operation at Pyne Gould Building, 2011. http:/ / www.kiwiblog.co.nz/2011/03/News/Asia-Pacific/New-Zealand

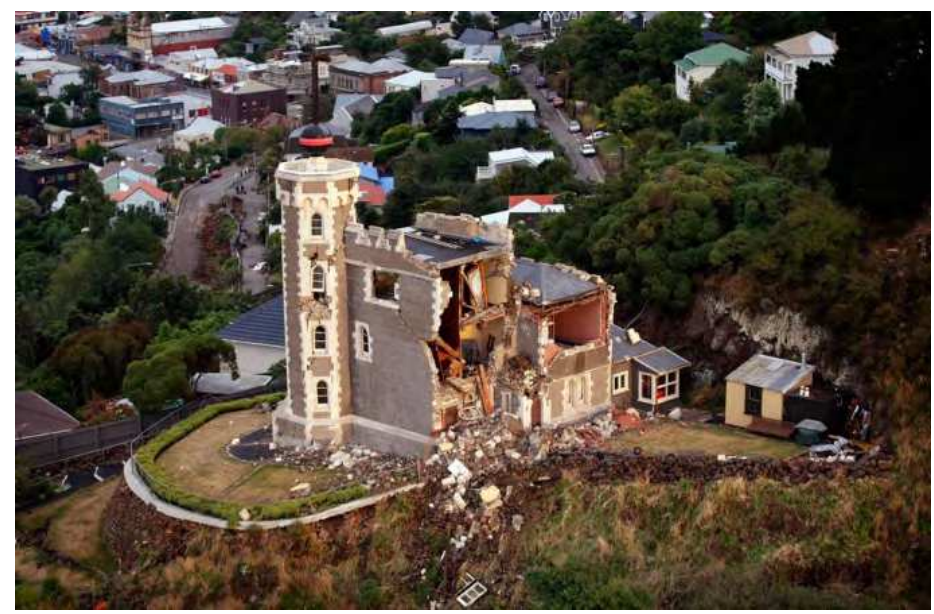

Fig. 30. Topographic Amplification May Play a Role in Damaging an Unreinforced Masonry Building, 2011. http://otilya.com/view/NewsAsia-Pacific/New-Zealand

\subsubsection{1 (Mw 9.0) Tohoku-Oki (East Japan) earthquake/tsunami}

Figure 31 shows the modelled slip distribution over the fault plane which triggered the Tohoku-Oki earthquake. The slip on the offshore rupture plane was about $30 \mathrm{~m}$, but the slip 
along the east coastline reduced to below $5 \mathrm{~m}$. Figure 32 shows acceleration time histories recorded in the earthquake region (NIED 2011). These records have been used to analyze structures such as the study of the response of high-rise buildings to long-period ground motions (Takewaki et al. 2011). It is worth to note that some of the records in Fig. 32 show multi-sequences of earthquake excitations. Moustafa and Takewaki (2010) indicated that such earthquake sequences would result in more severe structural damages due to the accumulation of inelastic deformations. Substantial damages were suffered by the buildings and infrastructures in such a major subduction event of long duration due to the combined effect of earthquake shaking and tsunami onslaught. Earthquake subsidence caused some coastal areas submerged in tidal water (see Fig. 33). JSCE (2011) provided an overview of the characteristics of the earthquake and tsunami; and damage reconnaissance including: geotechnical and structural damage, liquefaction, damage to dykes and levees, and bridges.

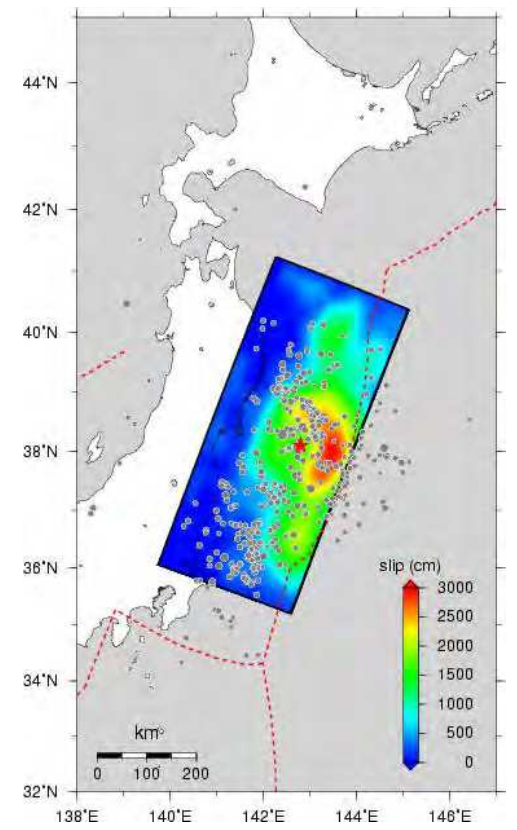

Fig. 31. Fault Plane Slip Distribution Tohoku-Oki, Japan. http://tectonics.caltech.edu/slip_ history/2011_taiheiyo-oki/index.html

Tsunami run-up height was in a range of 4 to $8 \mathrm{~m}$, with a maximum of up to $38 \mathrm{~m}$. The existing tsunami-protection seawalls and gates in the coastal region were overrun in places causing significant destruction. As a result, the numbers of casualty $(15,840)$ and missing people $(3,546)$ tend to be high for Japan, a seasoned country having invested heavily in the preparation for and defence against the frequent seismic and tsunami events. Emergency response efforts were hampered by fuel shortage, telecommunication and transportation disruption, damage to fire and police stations and hospitals and nuclear radiation.

The destructive power of earthquake and tsunami has long been experienced and recognized by human race since its existence. However, 2011 Tohoku-Oki earthquake has 
revealed another relatively modern threat, i.e., the trigger of a long-lasting and potentially deadly nuclear incident. Salt water intrusion into pumping systems resulting in equipment failures has been reported earlier such as in the 1993 Hokkaido and 2004 Sumatra events. This relatively minor problem usually only led to delay in the restoration of the water and sewer systems. Nevertheless, at the Fukushima Dai-Ichi nuclear generating station (see Fig. 34), the disruption of the cooling systems of nuclear reactors and power failure resulted in the meltdown of reactor fuel rods.

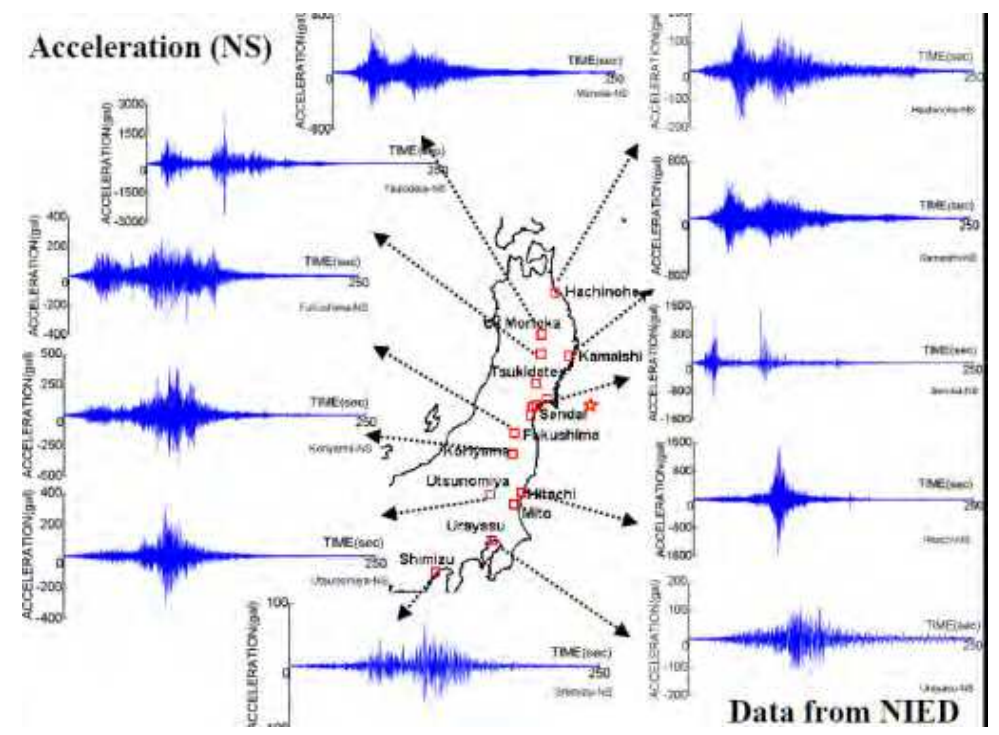

Fig. 32. Ground Acceleration Time histories Recorded in Earthquake Region. (NIED 2011)

It is reported that during risk assessment of the nuclear power station prior to the earthquake, a tsunami expert was overruled by an executive, when the survivability of the reactors in a potential tsunami event was raised. Thus, the design flaw at this plant was not corrected, while another plant with a newer design survived the current event without problem. Construction records also revealed that in 1967, the owner, Tokyo Electric Power, excavated 25 metres off the 35-metre high natural ground where the reactors were to be located. The lowering of the site grade appeared to facilitate equipment transportation as well as pumping of seawater for cooling the reactors.

The current solution is to abandon the power station, and to eventually entomb the damaged reactors in concrete after their cool-down, even though ongoing radiation leak continues to contaminate the plant site, its surrounding land and sea five months after the earthquake (August 2011).

A mandatory 15 per cent cut of peak-time power consumption is in force this summer (2011) for large users in and around Tokyo. Only nineteen of the 54 Japanese reactors that were in service prior to the March 11 earthquake are working in July 2011, because of local opposition. It is uncertain how long will it take to bring the radiation problem at the Fukushima Dai-Ichi plant site under control. Germany and Switzerland have indicated their 
plan to phase out nuclear power plants, while other countries have also starting the reassessment of their future nuclear-power development plans. Thus, the radiation concern for all nuclear power plants has to be carefully evaluated, and robust defence measures against natural and man-made hazards have to be implemented around the world.

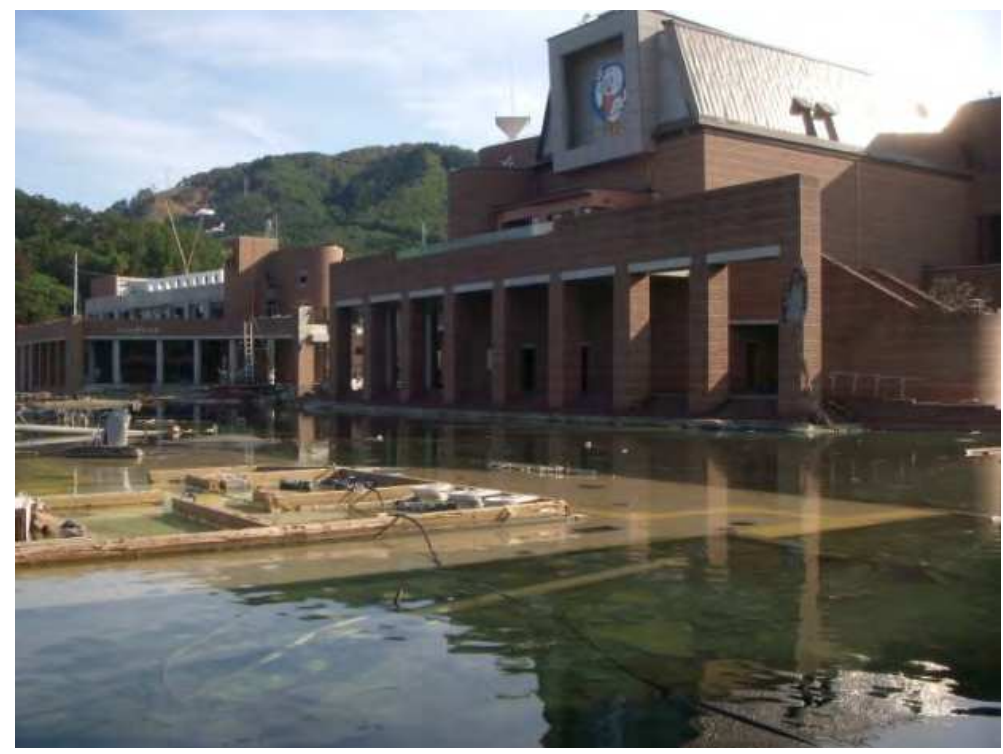

Fig. 33. Waterfront Buildings in Onagawa, Japan Inundated by Tidal Water Due to Earthquake Subsidence. http://tectonics.caltech.edu/slip_history/2011_taiheiyooki/index.html

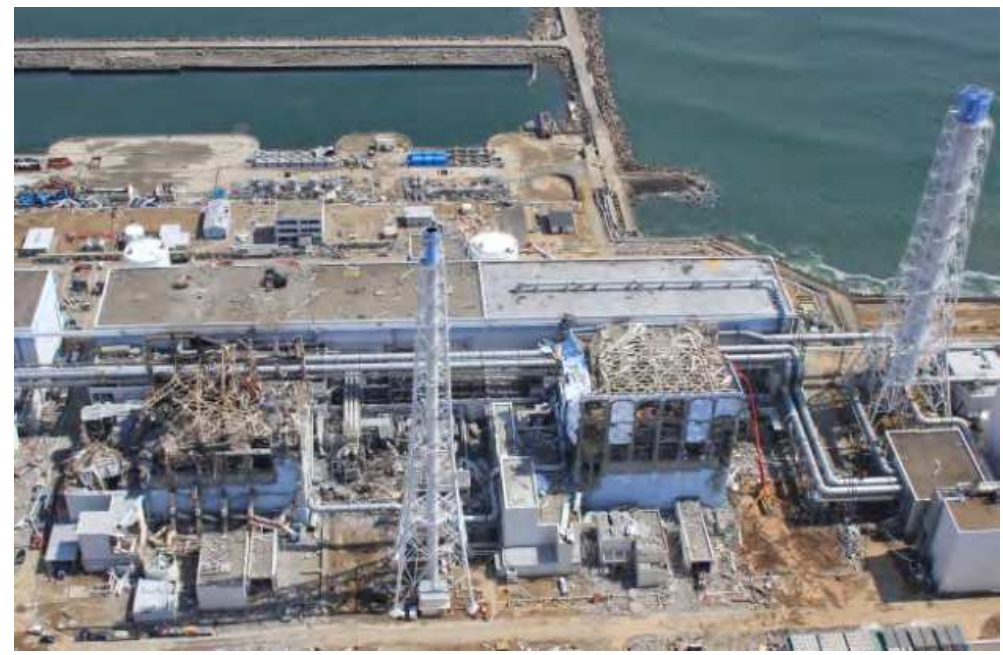

Fig. 34. Blast-Damaged Fukushima Dai-Ichi Nuclear Power Plant Unit 3 (left) and Unit 4 (right).http:// pinktentacle.com/ 


\section{Geoscience and geotechnical aspects}

Geoscience and geotechnical aspects of those earthquakes covered in Section 2 and Table 1 are discussed here together with other relevant events (Lo and Wang 2008).

\subsection{Geoscience aspect}

- Earthquake events inflicted heavy loss of life and property as well as disrupting businesses. They illustrate the high risk of structure inadequacy in populated and developed areas vulnerable to seismic hazard.

- Tsunami hazard to coastal population can be mitigated by advanced warning and physical barriers such as sea walls and gates. However, when warning system is either not established (Sumatra 2004) or insufficient evacuation time is available due to proximity to the fault rupture, and the physical tsunami barriers are overrun (TohokuOki 2011), the tragic loss of lives and properties is severe.

- Earthquakes usually occur according to a typical pattern, starting with a single main event, maybe preceded by foreshocks, followed by a series of smaller aftershocks that would diminish in magnitude and number with time. Exceptions to this pattern are not uncommon. In fact, the concept of "earthquake conversations" (Stein, 2003 and 2005) suggests that the hypothesis of stress-triggering of earthquake may be the mechanism controlling earthquake occurrence. As population centres around the world grow from isolated metropolitans to more or less continuous industrialized belts, the following earthquake patterns observed in recent years deserve more attention in order to mitigate damages.

- $\quad$ Numerous large aftershocks of the Sumatra 2004, Maule 2010 and Tohoku-Oki 2011 subduction events, and the rupture of an adjacent segment of the locked plate boundary offshore such as the Nias 2005 event or the increased threat to the Tokyo region after the Tohoku-Oki 2011 event, and a Mw 6.9 crustal (or intraslab) normalfault event on March 11, 2010 in the region of Libertado O Higgins in Chile triggered by the February 27, 2010 subduction event;

- Several large regional seismic events occurred within several months after the Wenchuan 2008 event due to stress readjustment in the region;

- The Christchurch 2011 aftershock of the Darfield 2010 event occurred much closer to the population centre;

- Turkey Kocaeli (August) and Düzce (November) earthquakes in 1999 - triggered by the rupture of two adjacent segments of the North Anatolian transform fault; and

- El Salvador January and February earthquakes in 2001 - an offshore intra-slab event followed by an inland crustal event.

Thus, major seismic events of various source mechanisms could occur in adjacent areas within a short time interval. This phenomenon has significant implications in earthquake design and restoration. First, there is a potential threat to the safety of personnel engaging in the emergency response. Secondly, any retrofitted structure may have to undergo severe seismic test during or shortly after its repair. It may no longer be acceptable to lower the design criteria for retrofitted structures, even though it has been currently practiced in many countries as the experience of Christchurch in 2010 and 2011 shows. 
- Earthquake investigation tools and methods have continually been evolved with significant recent advances, such as:

- Global Positioning System (GPS) - GPS has been increasingly deployed along major faults to provide continuous deformation data over the tracked GPS stations;

- Interferometric Synthetic Aperture Radar (InSar) - InSar is a satellite remotesensing technique used to track areal ground deformation adjacent to faults. Both GPS and InSar are used to monitor the ground deformation along major faults and/or in highly seismic areas before and after earthquake occurrence; and

- Satellite imagery, such as Google Earth and high-resolution imagery, and Light Detection and Ranging (LiDAR) have become standard tools used for the study of post-earthquake damages. A workshop was conducted by the Global Earth Observation Catastrophe Assessment Network (GEO-GAN 2010) to review the use of high-resolution satellite imagery with the coordinated efforts by volunteering professionals to conduct rapid structure damage assessments, geotechnical studies and landslide surveys. The development started in 2008 for studying the Wenchuan earthquake, and expanded in 2010 for the Haiti earthquake, involving verification of the assessment results by field reconnaissance on the ground (see www.virtualdisasterviewer.com).

- Digital seismographs - Newly installed digital seismographs capture a wide spectrum of seismic ground motions accurately and efficiently and can be easily transmitted to regional centers for further data processing than their earlier analog counterparts. The number of strong-motion accelerograms available for seismic design analyses have increased drastically in recent years including from four of the six events discussed here with the exception of the 2004/2005 Sumatra and 2010 Haiti events.

- Coral as natural record of relative sea-land movement (see Fig. 35) - Coral has been successfully used by researchers to study co-seismic and inter-seismic ground movements caused by inter-plate subduction earthquakes (Caltech 2011).

- Internet - The internet has been used by the United States Geological Survey for conducting earthquake intensity survey, and by the earthquake investigators to coordinate international investigation efforts through dedicated websites, links, individual blogs and social media. Such widespread use of electronic communication could potentially be harnessed as an effective, informal means to spread tsunami warning, especially to distant coastal areas to reduce the likelihood of repeating the 2004 Sumatra tsunami tragedy.

- Information technology - Modern equipment such as digital camera, GPS, laptop and satellite communication, etc. all contributes to the efficiency of an individual investigator.

\subsection{Tsunami and geotechnical aspects}

Earthquake secondary effects refer to non-tectonic surface processes that are related to earthquake shaking. They are often spectacular in expression and are main causes for loss of life and property. These effects include: tsunami, landslide, rockfall, turbidite (dense, sediment-laden flow offshore), liquefaction and lateral spreading, and site amplification, etc. (Lo et al. 1996). Their preserved geologic signatures sometimes serve as paleoseismic evidence for strong ground motion of prehistoric earthquakes (Yeats et al. 1997). 


\subsubsection{Tsunami effects}

- Forces associated with tsunami - In addition to the inundation effect of rapidly moving waves, tsunami also exerts additional physical forces to structures such as hydrodynamic pressure including uplift (see Figs. 36, 37 and 38), debris impact and wave scour (see Figs. 39 and 40). The overturning of seawalls could be caused by the combined effect of tsunami hydrodynamic pressure, uplift and scour. Both passive and active measures are used to mitigate tsunami damage. Passive measures are use of buffer zone and/or natural barriers such as mangroves and sand dunes to avoid building structures in near shore areas. Where structures are required in tsunamivulnerable zone, both inundation effect and tsunami-related forces have to be considered in the overall design and operation of these structures. Well designed concrete buildings, which have crawl space on the first floor to allow tsunami flowing through, performed well (see Figs. 41 and 42). However, the "soft-story" effect under seismic loading condition should be carefully evaluated.

- The important impact of tsunami hydrodynamic pressure on the performance of port facilities and bridges have been recognized for some time, vertical restrainers to counteract the tsunami uplift force against bridge decks such as experienced in the Maule and Tohoku earthquakes are proposed by Kawashima (2011). Policy to require vessels leaving the ports and sailing to the sea upon receiving tsunami warning would prevent damage to the vessels as well as port infrastructures from vessel impact.

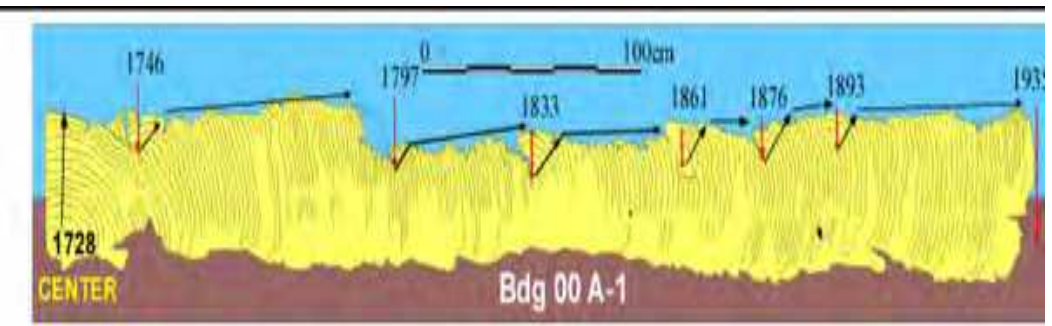

BDG-00-A1 graph

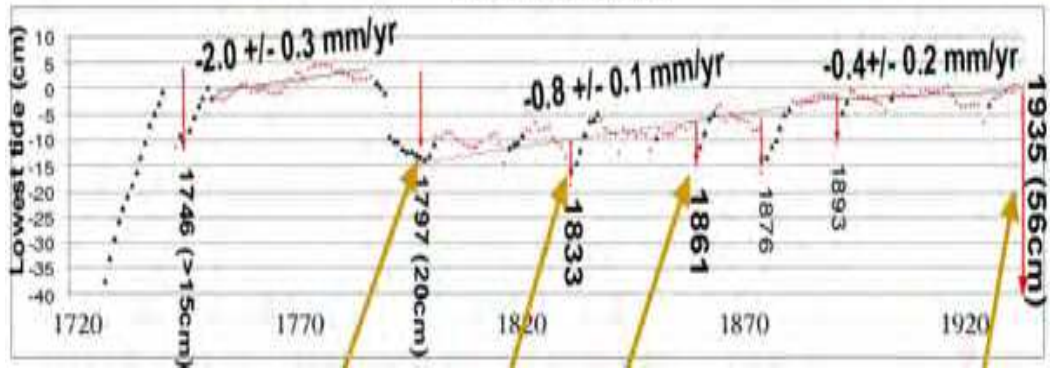

Fig. 35. Sea Level Changes Inferred from Truncated Coral Growth Rings. (Caltech 2011) http://www.tectonics.caltech.edu/images/sumatra/coral_record_web.jpg 


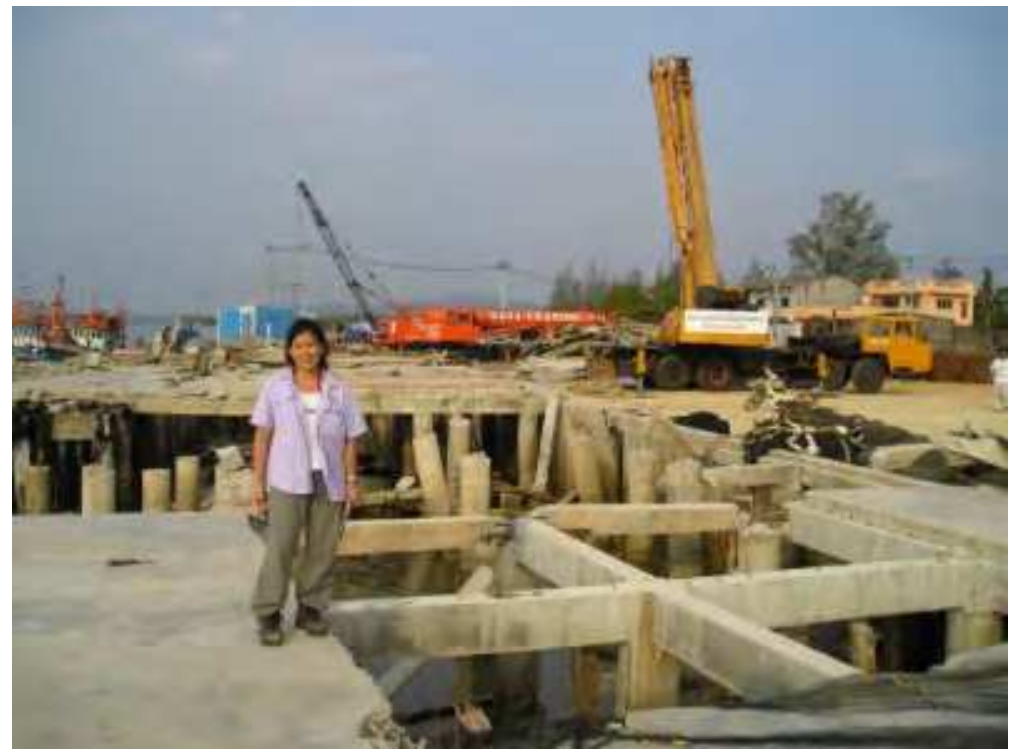

Fig. 36. Wharf Damaged by Wave Impact and Uplift, Bam Nam Kem, Phang Nga Province, Thailand, 2004.

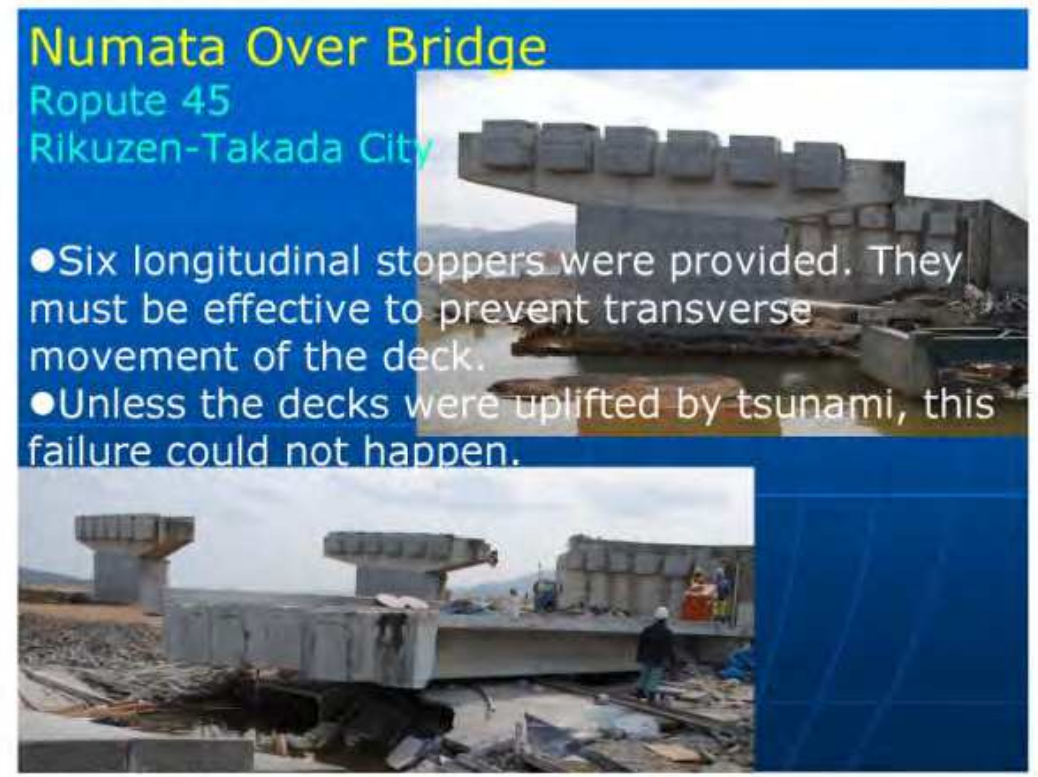

Fig. 37. Uplift of Bridge Deck In Spite of Longitudinal Stoppers - Tohoku Earthquake. (Kawashima 2011) 


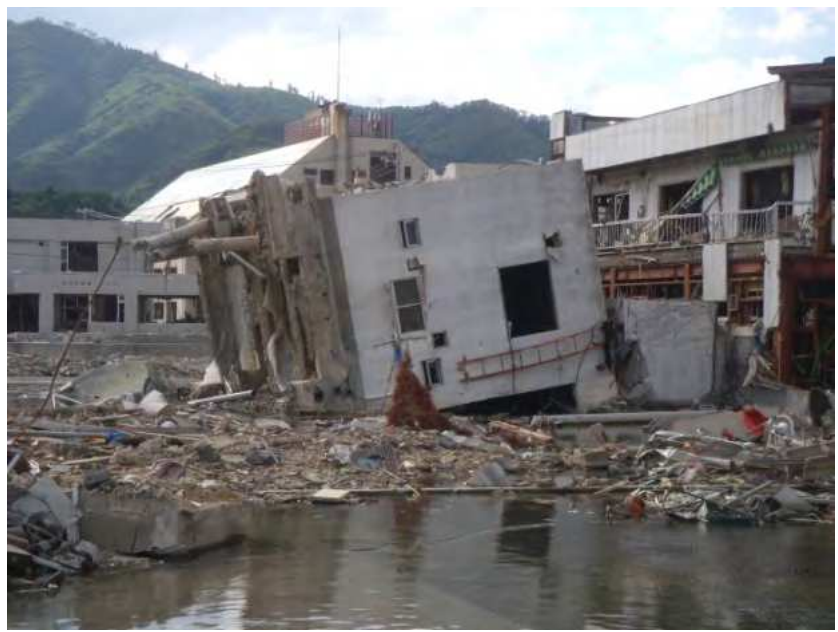

Fig. 38. Overturned Police Station, Onagawa, Japan, 2011.

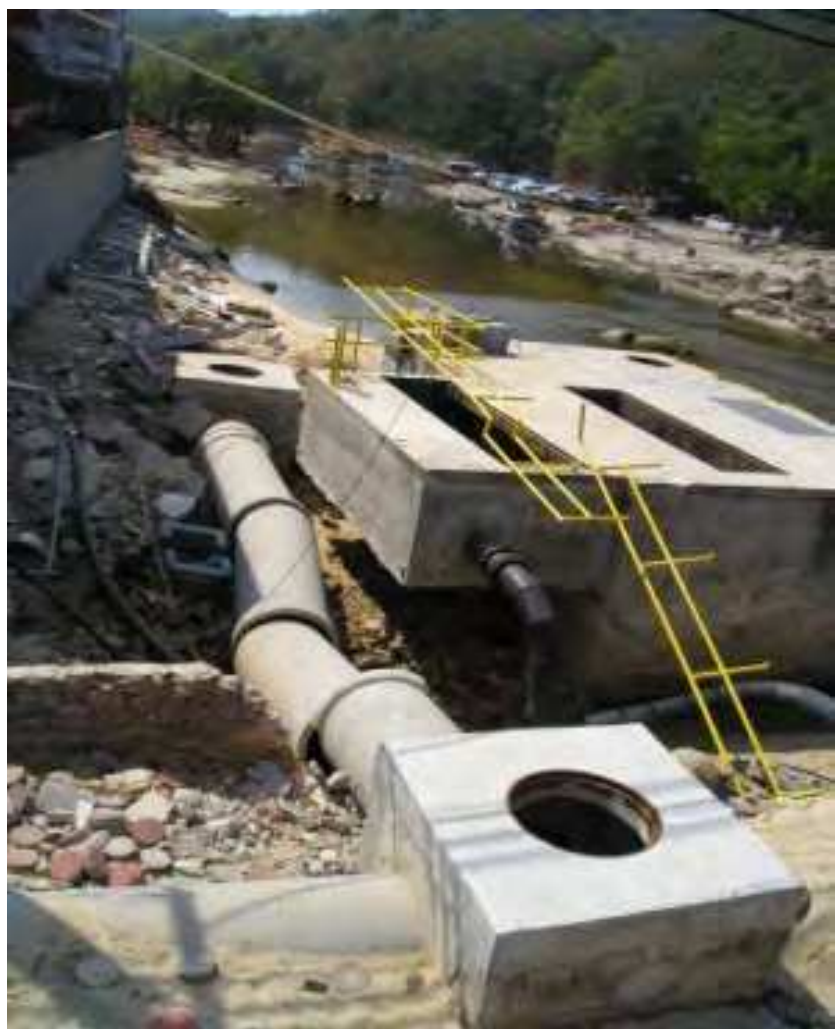

Fig. 39. Pump Station Damaged by Wave Scour, Patong Beach, Phuket Province, Thailand, 2004. 


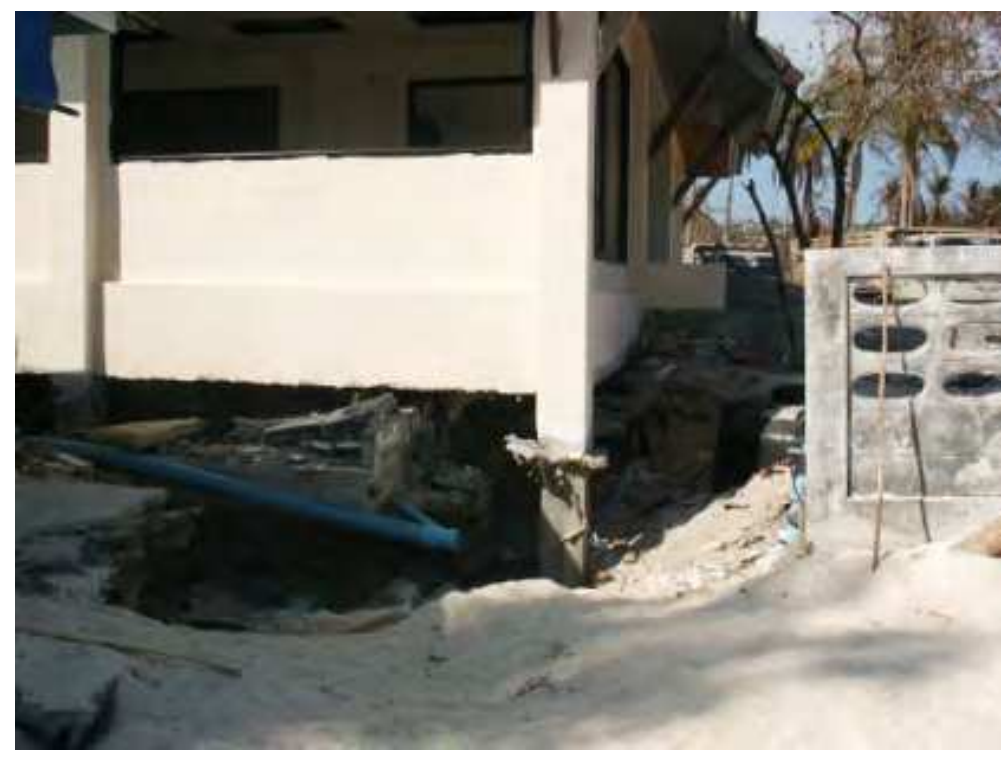

Fig. 40. Scouring of Foundation Soils and Severing of Building's Utility Lines, Phi Phi Island Hospital, Thailand, 2004.

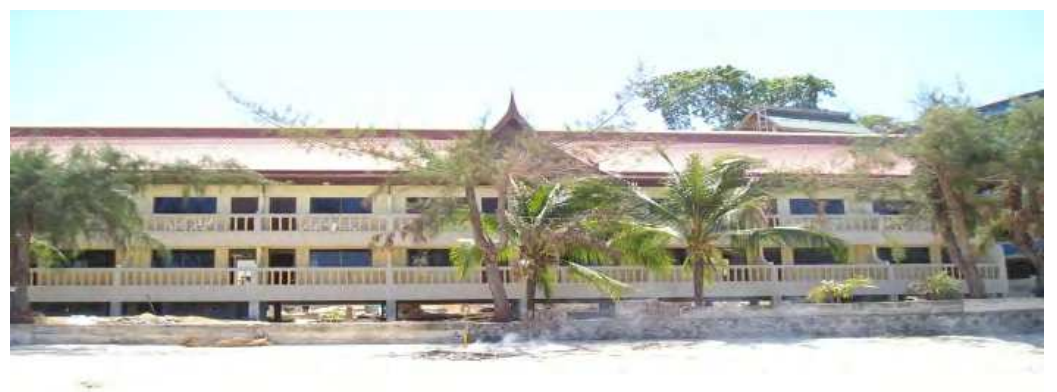

Fig. 41. Building with Crawl Space on the First Floor, Kamala Beach, Phuket Province, Thailand, 2004.

\subsubsection{Ground failure effects}

Ground failure includes landslide, slope failure, liquefaction, lateral spreading, bearing capacity failure, underground failure and ground displacement:

- Landslide - Correlations between the number of landslides and earthquake magnitude have been established around the world. In regions with pyroclastic deposits, the number of landslides for a given magnitude far exceeds those in other regions due to the relative large void ratio and weak strength of these deposits. The areas threatened by a landslide include the sliding land mass as well as the area traversed by the fast- 
moving sliding debris (see Fig. 43). The presence of water in the soil mass, as reflected in its degree of saturation, increases the probability of triggering a slide during an earthquake. Thus, whether the occurrence of earthquake is in dry or wet season could have significant difference in its impact. Heavy precipitation in earthquake stricken area could trigger post-earthquake landslides, debris flows and/or lahars (mudflows of volcanic debris). Moreover, the amount of water within the sliding mass and/or being entrained along its moving path increases its run-out distance and, hence, downstream impact. The local topographical detail along the debris travel path dictates the area being buried by the slide debris. The formation of a landslide lake, caused by temporary blockage of river by unstable slide debris, poses a special flood hazard. Timely construction of a spillway to drain the lake is required to ameliorate the downstream flood hazard such as the case with the Tangjiashan Landslide-Lake after Wenchuan 2008 earthquake (see Fig. 11).

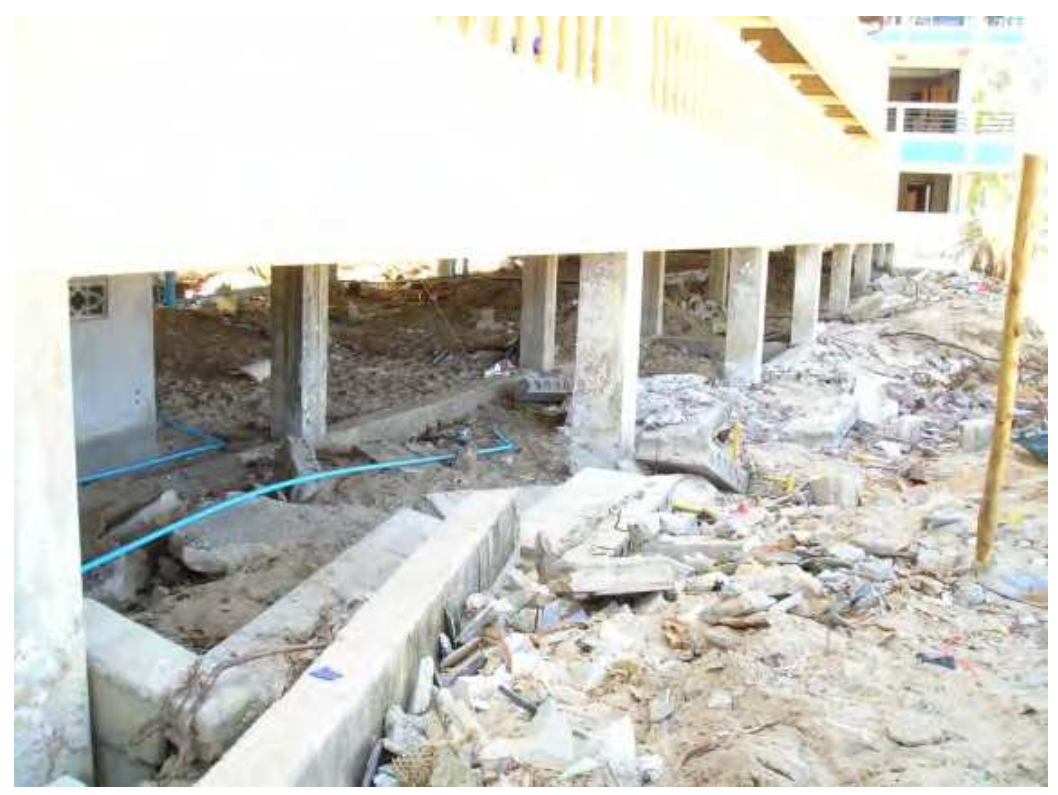

Fig. 42. Close-up of Fig. 41, Showing Inter-connected Grade Beams and Columns.

- $\quad$ Slope failure - Failure in natural or man-made slope occurs where the available effective shear strength is exceeded by prevalent shear stress due to the earthquake-induced pore pressure increase and/or presence of inertia force during earthquake shaking. Slope failure of highway and/or railway embankment could disrupt vital transportation link and wrought havoc in the community life and regional economy as evidenced in all major earthquakes. Cracks and upstream slope slump of the 26-m high Fena earth and rockfill dam after Guam earthquake in 1993 required emergency repair by U.S. Navy Seebees.

- Liquefaction and lateral spreading - Liquefaction and lateral spreading could occur in much gentle slopes or level ground, where the soil deposits involve relatively loose cohesionless materials such as sand and silt and occasionally gravelly soils. Loss of shear strength and associated ground movements would affect structures located in 
areas with high groundwater table, such as low-lying areas, river banks and ports, and lead to slope failure, lateral spreading, foundation horizontal displacement and settlement or uplift, bearing-capacity failure, and rupture of lifelines. Emergency repair of flood-control dykes or levees damaged by liquefaction of subsoils was often needed such as after Tohoku-Oki earthquake (see Fig. 44). The Tohoku-Oki earthquake caused levee damage at over 2,000 locations.

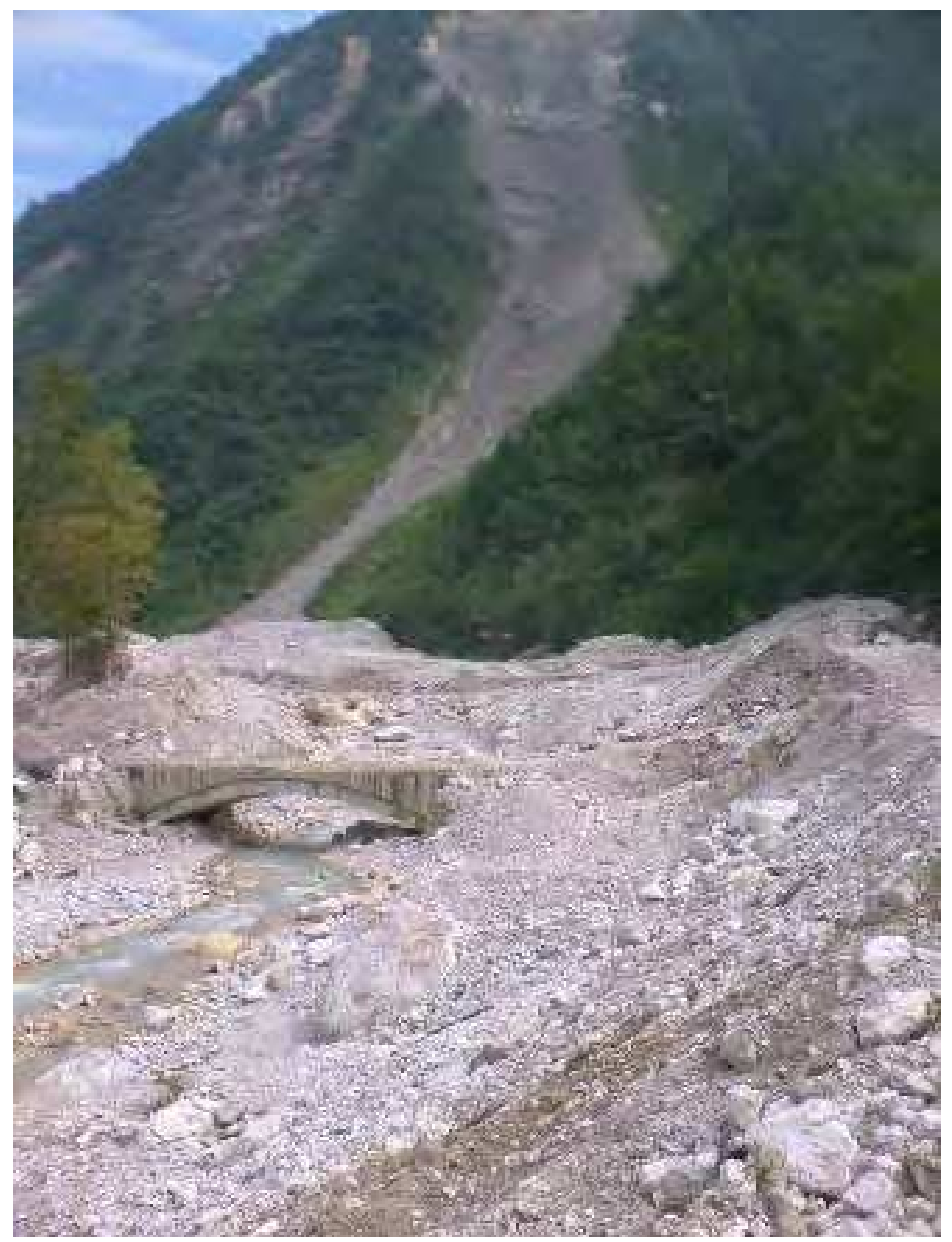

Fig. 43. Debris Flow at Huosigou, Chongzhou, China, 2008.

- Bearing-capacity failure - Foundation bearing-capacity failure also occurs in cohesive soil due to the softening effect of earthquake shaking. The punch shear failure of footings is associated with soil heave in the adjacent area. For tall and narrow buildings with an aspect ratio (height/width) greater than 2, it could lead to severe tilting or 
overturning of the building (see Fig. 45). This type of foundation behavior was observed in Mexico City due to the presence of sensitive Mexico City clay during the 1985 Michoacan earthquake, and again in Adapazari City due to the presence of Holocene alluvium during the 1999 Kocaeli earthquake.

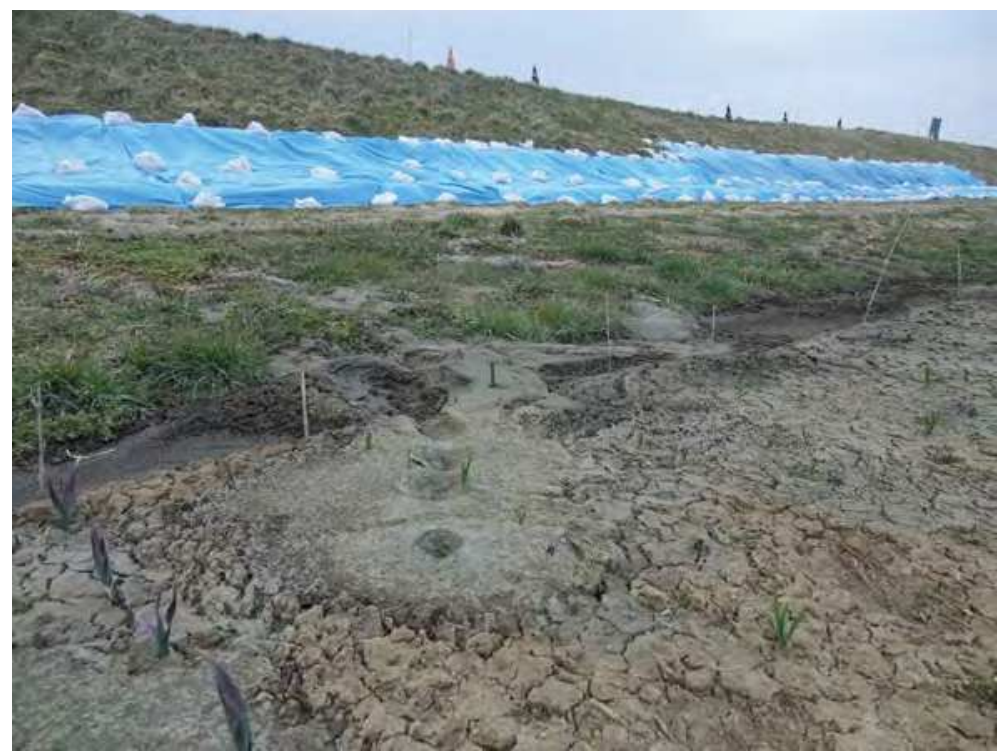

Fig. 44. Levee Slope Repair and Sand Boils at Toe, Japan. (JSCE 2011)

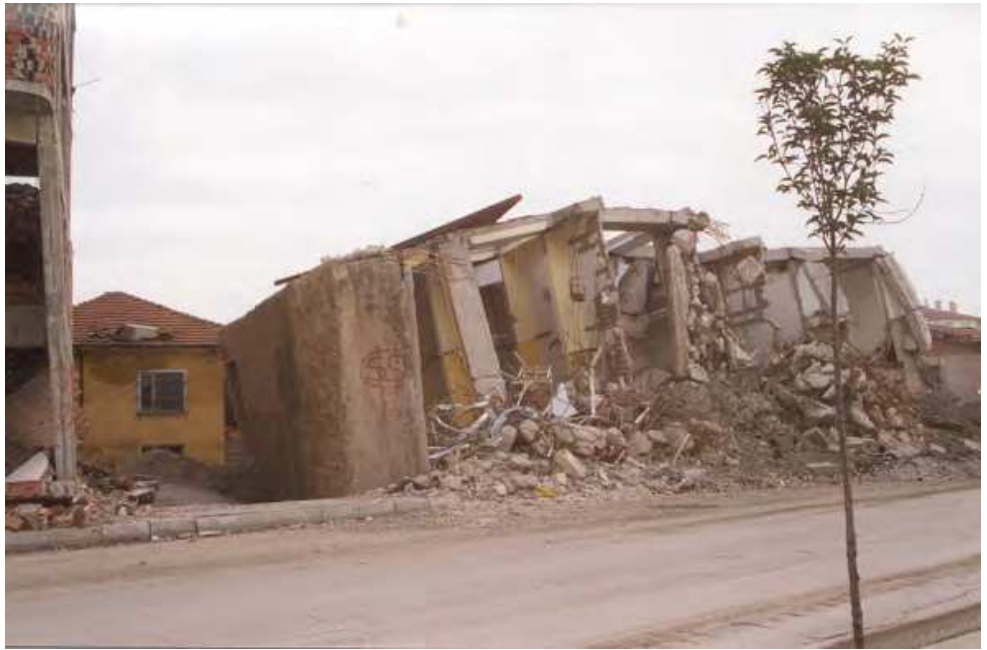

Fig. 45. Overturned Building of High Aspect Ratio in Adapazari City, Turkey, 1999.

- $\quad$ Surface expression of underground failure - Sinkhole may occur during an earthquake. The phenomenon appears to be puzzling until the cause is identified. Usually, sinkhole 
occurs where pre-existing underground voids already formed prior to the earthquake. These voids may be formed by solution of limestone, abandonment of mine workings or "piping" erosion of fine soils by groundwater flow. In other situation, earthquaketriggered failure of underground structure could also result in the formation of sinkholes. The former examples are sinkholes occurred along highway culverts in El Salvador and Nisqually earthquakes where "piping" erosion of backfill around the culverts was present (see Fig. 46), and sinkholes occurred at the abutment of Matahina Dam in New Zealand (Gillon and Newton 1991). The latter example is the sinkholes formed due to the collapse of Bolu Tunnels after the 1999 Düzce earthquake. At Christchurch, concern of voids formed underground due to massive loss of sand to the surface because of liquefaction was raised (see Fig. 26).

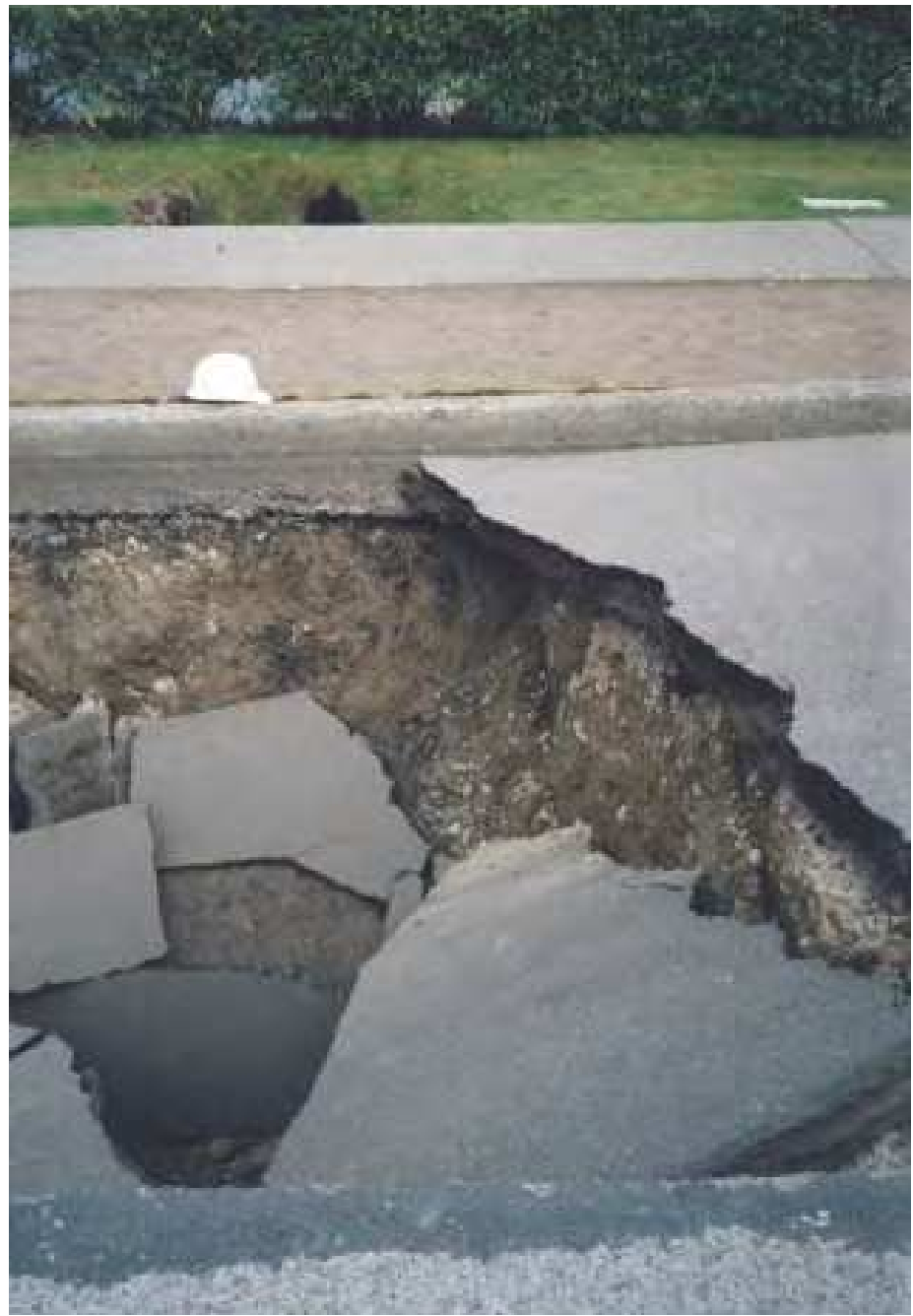

Fig. 46. Sinkhole Formed by Collapse of Roadway During Earthquake, Washington, 2001. 
- Ground displacement - Ground displacement includes tectonic movement or nontectonic surface processes. When it occurs within the footprint of structures, it affects the structural stability and integrity. Where lifelines intersect fault traces, the impact of potential ground displacement related to fault rupture is a major design challenge as the experiences in Wenchuan, Kocaeli and Dücze earthquakes show. On the other hand, differential settlement of approach fill and pile supported bridge deck at bridge abutments is a frequently recurring scene, e.g., at Christchurch (see Fig. 47). Subsoil volume decrease would lead to foundation settlement with no adjacent soil heave.

\subsubsection{Ground shaking effect}

- Site amplification - Site amplification of ground motion through soft soil deposits has been well recognized and incorporated in the modern seismic design codes. However, severe building damages suffered at soft sites at Adaparazi and Avcilar during 1999 Kocaeli earthquake reiterate the importance of this phenomenon. Avcilar is near Istanbul and about $80 \mathrm{~km}$ west of the epicenter. The distance attenuation of ground motion was more than compensated by local site amplification. Similarly, topographic amplification of ground motion was also evident during Christchurch (see Fig. 30), and all other recent earthquakes.

\section{Lessons learned from earthquakes}

\subsection{General}

Earthquake damage in a given area tends to reflect its social-economic condition. Thus, wide spread damage to sub-standard structures and heavy loss of life seem to recur unfortunately too frequently. Comartin et al. (2004) considered that reducing high loss of life from earthquakes is the most important challenge facing the global earthquake engineering community. Efforts underway to meet this challenge included: improving construction practices in individual countries such as India and Columbia and promoting international collaboration and information sharing. The EERI/IAEE World Housing Encyclopedia is a valuable platform to spearhead this ongoing effort.

Conversely, in areas where earthquake-resistant design codes and engineering practices are kept up-to-date, damage tends to be limited to older and inadequately designed structures, or areas with special site conditions. However, this general observation may have exceptions such as in Christchurch, New Zealand and Tohoku, Japan, when potential seismic hazards are under-estimated.

Outlined in the following are some of the lessons learned from the recent earthquakes:

- Tsunami warning - Timely warning of tsunami and evacuation drill are prerequisites for saving lives in such an event. Sumatra earthquake-tsunami is an unprecedented tragedy to illustrate this point, and provided an impetus for the set up of a tsunamiwarning system for countries around the Indian Ocean. Adequate warning requires the implementation of a system involving instrumentation on land and on ocean floor, and international organization and communication protocol. The system has to be maintained vigilantly to be effective. While warning against tsunamis triggered by distant earthquakes is adequate in North America, further work is required for warning 
and protection against tsunamis caused by nearby earthquakes as demonstrated in the experience of 2010 Maule, Chile and 2011 Tohoku-Oki, Japan events.

- For inhabitants living along vulnerable shorelines, running to high grounds or elevated structures, when feeling earthquake shaking or seeing unusual signs of waves including receding sea water or advancing wave, remains to be practical means to escape drowning by tsunami. Tragedy in the recent Chilean and Japanese events, however, remind us that the success of escape is not guaranteed, when the time window for survival is measured in minutes rather than hours, especially for elder or handicapped members of the population. The need for reliable near field (local) tsunami warning was further demonstrated in the case of 2005 Nias earthquake. About three months after the Sumatra earthquake, the tsunami-scared populace was all too eager to run for their life after given the warning. Nevertheless, no significant tsunami was realized this time. The ensuing evacuation commotion, and other false tsunami alerts in the wake of the 2004 Sumatra earthquake served to emphasize that the conduct of timely and reliable tsunami warning and orderly evacuation remains both a technical and societal challenge. Similar confusions to a lesser extent were also reported in some of the tsunami alerts in the North America.

- Tsunami vertical evacuation refuges - are an engineering option for enhancing public safety against near-field earthquakes (FEMA 2008/2009). These structures should be clearly identified as tsunami-proof refuges. They need to be designed for both earthquake and tsunami loads, as well as to a safe height above the tsunami run-up, allowing for rapid public ingress and upward movement (see Fig. 48). As a costeffective measure, any elevated structure in a tsunami-vulnerable zone such as water tower, lighthouse or fire-lookout tower could be designed with additional capacity and features to accommodate tsunami-escapees looking for an escape path.

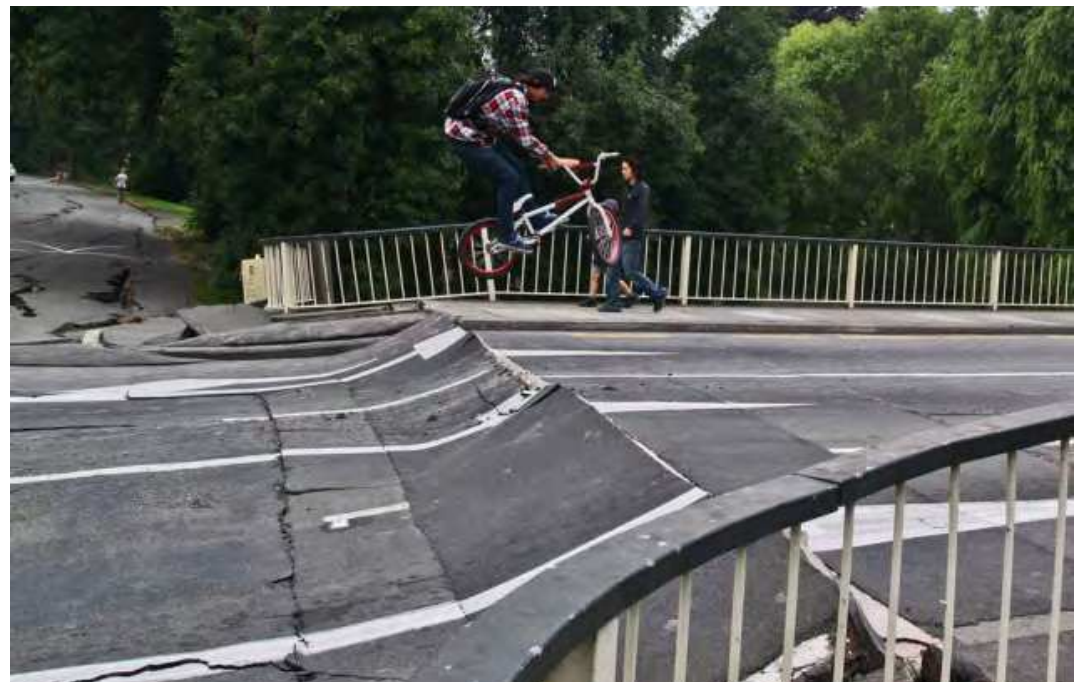

Fig. 47. Settlement of Approach Fill at Bridge Abutment Formed a Bike-Jump for a Youngster. http:/ / otilya.com/view/News / Asia-Pacific/New-Zealand 


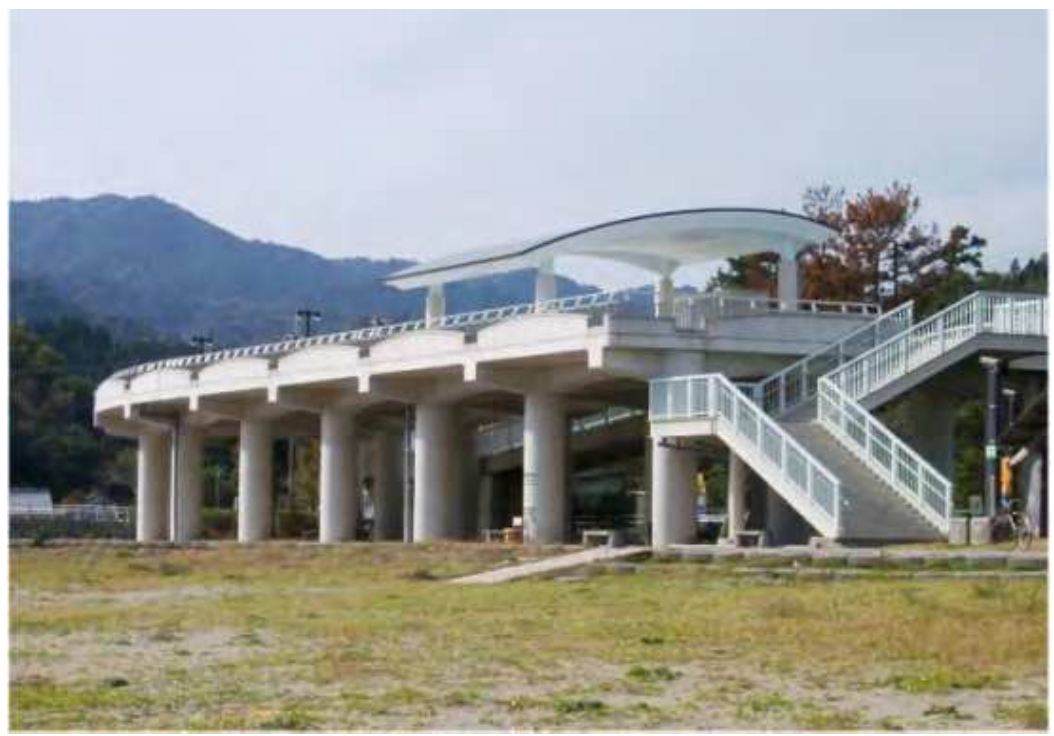

Fig. 48. Vertical Evacuation Structure at Shirahama Beach Resort in Japan. (FEMA 2009)

- Instrumentation for strong ground motion - Installation and maintenance of modern instrumentations for recording strong ground motion are important to characterize earthquake motion. Further instrumentation to measure the response of critical structures would improve the understanding and analysis of seismic behavior of the instrumented structures. However, lack of strong motion data in epicentral areas at Port-au-Prince, Haiti; Sumatra and Nias, Indonesia serve to indicate that it is not always feasible to achieve this goal due to economic, political and/or technical constraints. Moreover, potential tsunami inundation should also be considered when selecting sites for strong motion instrumentation.

- ASCE (2011) published a special issue on the selection and modification of earthquake ground-motion for nonlinear dynamic analysis of structures. The suite of 17 papers provides useful information about the ground-motion input in the nonlinear response-history analysis of structures. In particular, Moustafa (2011) outlined a new framework for modelling design earthquake loads for inelastic structures, using the method of critical excitations and adopting damage indexes to reflect the structure damage level.

- $\quad$ Land use - Microzonation is to be prepared for identifying areas susceptible to tsunami run-up, strong earthquake shaking, ground failures such as landslides, fault displacements, slope failures and liquefaction, etc. Determination of appropriate land use should then be guided by the identified hazards to mitigate potential loss.

- Seismic design - Update of seismicity hazard and upgrade of seismic design are to be carried out on a regular basis. Although the replacement of vulnerable structures before they are decimated by earthquake could prevent avoidable loss of life, funding required for such an undertaking seems always difficult to come by, especially during the current weak financial condition around the world. Up-to-date seismic design measures should be implemented in new structures. Whenever possible, retrofit of existing structures should be facilitated by legal requirements and/or financial incentives. 
- Emergency response and public education - Drills of emergency response need to be practiced regularly to enhance the capability of response agencies and personnel, and public awareness. Preservation of certain damaged or failed structures in the earthquake-stricken areas as memorial sites would go a long way to remind and educate the public about the importance of adequate seismic design and earthquake preparedness. Figure 49 shows the memorial park established at the preserved old Beichuan townsite in honour of the victims, and Figure 50 shows the public taking a sober earthquake lesson at the park.

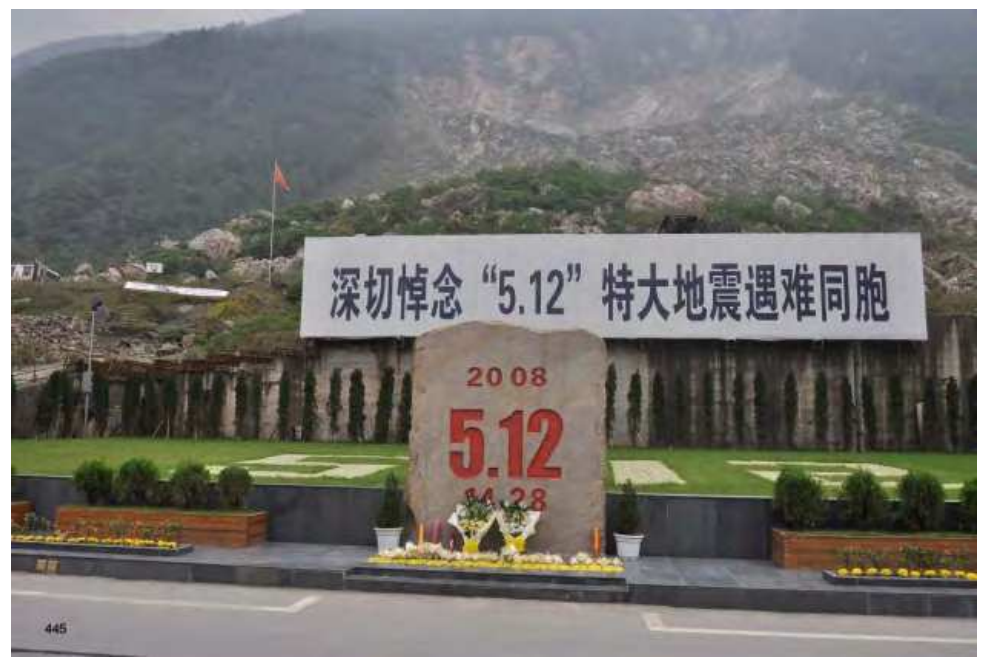

Fig. 49. Memorial Park at Old Beichuan Town. http://www.eeri.org/site/meetings/ uschina-symposium

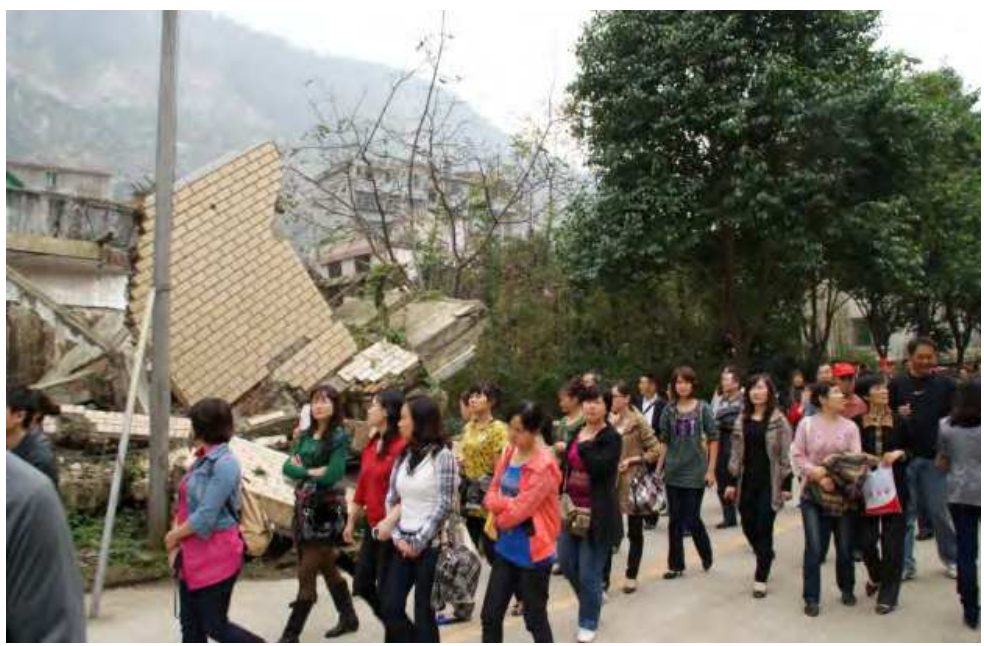

Fig. 50. Educational Tour of Memorial Park. http://www.eeri.org/site/meetings/us-chinasymposium 
- Potential impacts on secondary damages by earthquakes such as tsunamis, fires, landslides, debris flows, dam breaches, disruptions of lifelines and release of hazardous material including radiation are to be considered in order to devise realistic response strategy, and to plan for orderly implementation of long-term upgrade of existing facilities.

\subsection{Lifelines facilities}

Lifelines are those systems required for the survival and function of societies, and include: water and wastewater, electric power, communications, transportations, natural gas and liquid fuels, etc. Human societies often evolved on the nodal points of the rivers and ports transportation networks located on flood plains. Thus, various geotechnical issues reviewed in Section 3.2 affect the seismic performance of lifelines facilities, such as rupture of water and waste water pipelines, disruption of power and communication lines, and damage to bridges, power transmission and communication towers, etc. due to foundation failures, liquefaction and lateral spreading.

Lessons applicable to lifelines facilities include the following:

- Fault Displacement - Fault displacement caused significant structure damages in the Wenchuan earthquake. Earlier examples are the collapse of Arifiye overpass across the Trans-European Motorway (TEM) in the Kocaeli earthquake (with about 3 to $3.5 \mathrm{~m}$ fault displacement) and significant displacement and damage to the Bolu Viaducts in the Düzce earthquake (with $1.5 \mathrm{~m}$ displacement of adjacent piers and $13^{\circ}$ rotation of pile caps across the fault). The impact of potential fault displacement on the performance of the sub- and super-structures crossing active faults remains to be a serious challenge to the designers.

- $\quad$ Review and Upgrade - The reliable service of a lifeline depends on proper functioning of all its important components at all times. It requires regular review and upgrade of these facilities in normal time as well as prompt repair of failed components after an earthquake.

- $\quad$ Redundancy - Robustness of the lifelines relies on the built-in redundancy. As a certain line or node of a given lifeline is down, the availability of alternate lines or nodes is critical for maintaining the lifeline function during the critical period of emergency response and restoration.

- Two 380-kV transmission lines bypassed the Adapazari substation, which suffered circuit-breaker damage during the Kocaeli earthquake. These two lines were critical to power restoration after the earthquake. This type of redundancy requires careful planning and consideration of a variety of potential damage scenarios based on knowledge of potential earthquakes and physical conditions of the lifelines facilities.

- Lack of redundancy in the cooling system of nuclear reactors at the Fukushima Dai-Ichi nuclear power plants is the fatal flaw. It eventually led to the meltdown of the fuel rods. It not only stopped power generation at the plants, but also disrupted and/or curtailed power generation at other nuclear plants due to the shadow that its incidents casted on the safety of nuclear power in general.

- Tsunami Inundation - One side effect of tsunami inundation during Sumatra earthquake was to cause pump failures due to salt water intrusion. This delayed the 
restoration of those water and sewer lines whose function relies on the pumps. Thus, sea water intrusion needs to be considered and guarded against or avoided in the design of water and wastewater systems. Moreover, contamination of agricultural irrigation and groundwater supply systems by sea water intrusion deserves careful attention.

\section{Conclusions}

Earthquake, with its potent destructive power associated with the sudden release of enormous energy stored over an indefinite period of seismic acquiescence, strikes terror in people's mind around the world. This chapter reviews six recent earthquakes, which occurred in 2004 to 2011, including three tsunami-generating subduction earthquakes (along the coastlines of the Indian Ocean, South and North Pacific Ocean) and three crustal events (in the interior of the Asia Continent and two islands in the Caribbean Sea and South Pacific Ocean). These earthquakes affected both developed countries (New Zealand, Chile and Japan) and developing countries (Indonesia, China and Haiti). Due to the economic and resources constraint, the ability of a country to direct its resources to cope with natural hazards inherent to its location and setting varies. Thus, both self development and international cooperation and assistance are important to enhance the overall capacity of each country to protect its population and economy against the ravage of earthquake and its associated secondary hazards. Summarized in the following are some of the observations gleaned and lessons learned and/or re-learned from recent and other relevant earthquakes:

\subsection{General observations}

- Post-earthquake investigation has evolved with the technology advancement over the years. The institutional support of this activity has been augmented many times by the individual voluntary efforts of professionals of various disciplines. The collaboration of research and practicing experts in these critical occasions promotes the development of appropriate technology that improves the survival chance of people and sustaining performance of structures for different regions of the world.

- The occurrence of a series of earthquakes in a given region, be it a main shock followed by aftershocks, or a foreshock followed by the main shock, or a sequential rupture of adjacent faults, deserves special attention in seismic design and post-earthquake response and reconstruction.

- The concurrent and/or secondary effect of earthquake, such as tsunami, ground failure, breach of man-made or landslide dam, release of hazardous material and fire hazard should always be considered. An even more serious and long-lasting hazard, i.e., the meltdown of fuel rods and radiation leak at nuclear power plant is now added to this list.

- The level of casualty and structure destruction, in general, reflect the engineering practice such as seismic building code and its enforcement, design and construction practice and workmanship in an area. Numerous and large-scale landslides further contributed to the destruction of the 2008 Wenchuan earthquake. Unreinforced 
masonry and non-ductile concrete buildings were the main structure type that suffered heavy damage in the 2008 Wenchuan, 2010 Haiti, 2010 Chile and 2011 Christchurch earthquakes.

- The heavy tsunami casualty in the 2004 Sumatra event was due to the absence of a warning system, while the higher than normal casualty in the 2011 Tohoku-Oki event was due to the unusually high tsunami run-up in places and relatively short time window available for evacuation of people from the low-lying areas.

\subsection{Lessons learned}

- The building code is a living document, which requires periodical review and update to reflect current understanding of the regional and local site seismicity, structural earthquake performance and latest design and technology. Any important new findings, such as the recognition of new or higher seismic hazard than that envisaged by the current code, should be carefully reviewed and implemented in the revised code as soon as practical.

- The high cost of re-building collapsed, demolishing unsafe, and retrofitting damaged buildings has caused some re-examination of the main objective of building code, i.e., to protect life safety of occupants and minimizing their injury. Beyond the life-safety objective, each jurisdiction may find its own optimal economic balance between the cost of initial design and construction, versus the cost and delay of re-construction after an earthquake. The current trend of structural design based on performance requirement will provide some flexibility to allow the adoption of a design higher than the minimum code standard based on life safety.

- Schools and emergency-response facilities, including fire and police stations, and hospitals, especially those located on weak subsoils prone to liquefaction, tsunamivulnerable zone, or site subject to geologic hazard such as landslides, rock falls, etc., should be relocated or retrofitted to meet the requirement of maintaining their function after an earthquake.

- Critical facilities, with high occupancies, or containing hazardous materials or susceptible to radiation leak, or serving important lifeline functions to society (e.g., power generation and distribution and telecommunication facilities), or have other sensitive parameters, should be designed and maintained at higher seismic standard.

- Major lifelines that are either co-located and/or are interdependent with respect to maintaining their proper function should have special performance requirements in order to avoid multiple and/or cascading lifelines failures.

- Emergency response and resilience plans for the region, and local jurisdictions should be developed and exercised. These plans should focus on robustness, redundancy, resourcefulness, and rapidity.

- Mutual-aid plans among adjacent jurisdictions, both locally and internationally, should be pre-arranged prior to the occurrence of earthquake so that the precious time required for effective rescue operations in the initial golden period of 72-hours will not be wasted. 


\section{Acknowledgements}

The authors wish to acknowledge the assistance they received from the librarians and administration staff of Klohn Crippen Berger for their effort in literature search and manuscript preparation, and from colleagues of ASCE TCLEE. The critical review and helpful suggestions by Professor A. Moustafa is greatly appreciated.

\section{References}

ASCE (2007). Sumatra-Andaman Islands Earthquake Tsunami of December 26, 2004, Technical Council on Lifeline Earthquake Engineering, Monograph No. 30.

ASCE (2011). Special Issue on Earthquake Ground-Motion Selection and Modification for Nonlinear Dynamic Analysis of Structures, J. Struct. Eng. 137 (3).

BBC (2005). http://news.bbc.co.uk/2/hi/science/nature/4247409.stm

BSSA (2007). The 2004 Sumatra-Andaman Earthquake and the Indian Ocean Tsunami, Bull. Seism. Soc. Am. 97, No. 1A, Jan.

BSSA (2010). The 2008 Wenchuan, China Earthquake, Bull. Seism. Soc. Am. 100, No. 5B, Nov.

Caltech (2011). http:/ / www.tectonics.caltech.edu/

Comartin, C. et al. (2004). A Challenge to Earthquake Engineering Professionals, Earthquake Spectra, Vol. 20, No. 4, pp. 1049-1056.

EEEV (2008). General Introduction of Engineering Damage of Wenchuan Ms 8.0 Earthquake, Jour. of Earthq. Eng. and Eng. Vib., Vol. 28. Supplement, October.

EERI Special Earthquake Reports. (2005 Mar. to Jul. Sumatra 2004/2005 Eqs.; 2008 Oct. Wenchuan 2008 Eq.; 2010 April and May Haiti 2010 Eq.; 2010 Jun. and Oct. Maule 2010 Eq.; 2010 Nov. Darfield 2010 Eq.; and 2011 May Christchurch 2011 Eq.). EERI Newsletters.

EERI (2006). Summary Report on the Great Sumatra Earthquakes and Indian Ocean Tsunamis of 26 December 2004 and 28 March 2005, W.D. Iwan Tech. Ed., Aug. and Earthquake Spectra, Vol. 22, Special Issue 3, June.

EERI (2011). The March 11, 2011 Great East Japan (Tohoku) Earthquake and Tsunami: Societal Dimensions, August.

FEMA (2008/2009). Guidelines for Design of Structures for Vertical Evacuation from Tsunamis, P646, May 2008, and Vertical Evacuation from Tsunamis: A Guide for Community Officials, P646A, June 2009.

Fierro, E. and Perry, C. (2010). Preliminary Reconnaissance Report - 12 January 2010 Haiti Earthquake, PEER.

GEER (2010/2011). Geo-engineering Reconnaissance of the 2010 Maule, Chile Earthquake, Version 2, May 25, 2010. and Geotechnical Reconnaissance of the 2011 Christchurch, New Zealand Earthquake, http://www.geerassociation.org/, 2011.

GEO-CAN (2010). Remote Sensing and the GEO-CAN Community: Lessons from Haiti and Recommendations for the Future, Global Earth Observation Catastrophe Assessment, Network Workshop Report, June. 
Gillon, M. and Newton, C. (1991). Abutment Repairs at Matahina Dam, Proc. of the 17th Congress on Large Dams, ICOLD, Vienna.

JSCE (2011). Preliminary East-Japan Earthquake Damage Investigation Report, Japanese Society of Civil Engineers, April 11. http://committees.jsce.or.jp/report/node/40 (in Japanese).

Kawashima, K. (2011). Damage of Bridges Resulted from East-Japan Earthquake of March 11, 2011, http://peer.berkeley.edu/news/wp-content/uploads/2011/04/EastJapan-Earthquake-21.pdf (in English).

Lo, R.C., Henderson, P.W. and Morrison, K.I. and Finn, W.D. Liam (1996). Seismic Geotechnical Considerations - An Overview, 11th WCEE Paper 1853.

Lo, R.C. and Wang, Y. (2008). Geoscience and Geotechnical Aspects of Recent Earthquakes, $4^{\text {th }}$ Conf. on Geotechnical Earthquake Engineering and Soil Dynamics, Sacramento, Calif. May.

Lo, R.C. (2009). May 12, 2008 Wenchuan Earthquake - Lessons Learned from Its Impact, Emergency Response and Recovery, ASCE TCLEE Conf. on Lifeline Earthquake Engineering in a Multihazard Environment, Jun 28-Jul 1, Oakland, Calif.

Moustafa, A. and Takewaki, I. (2010). Modeling Critical Ground-Motion Sequences for Inelastic Structures, Advances in Structural Engineering, Vol. 13, No. 4, pp. 665679.

Moustafa, A. (2011). Damage-Based Design Earthquake Loads for Single-Degree-of-Freedom Inelastic Structures, ASCE J. Struct. Eng. 137 (3) pp. 456-466.

NBCC (2005). National Building Code of Canada, National Research Council.

NIED (2011). National Research Institute for Earth Science and Disaster Prevention, http://www.bosai.go.jp/e/index.html.

PEER (2011). Preliminary Briefing on Japan's Tohoku Earthquake, Aftershocks, and Tsunami of March 11, 2011.

Somerville, P. (2000). Seismic Hazard Evaluation, 12th WCEE, Paper 2833.

Stein, R.S. (2003, 2005). Earthquake Conversations, Scientific American, pp. 72-79, January, 2003 and pp. 82-89, Sp Vol. 15, 2005.

Takewaki, I. Murakami, S., Fujita, K., Yoshitomi, S., and Tsuji, M. (2011). The 2011 off the Pacific coast of Tohoku earthquake and response of high-rise buildings under long-period ground motions, Journal of Soil Dynamics and Earthquake Engineering.

UN OCHA (2005). Relief Web Map Center, United Nation Office for the Coordination of Humanitarian Affairs, Jan. 3.

USGS (2004-2011). Significant Earthquake and News http://earthquake.usgs.gov/earthquakes/eqinthenews/

USGS/EERI (2010). The Mw 7.0 Haiti Earthquake of January 12, 2010, USGS/EERI Advance Reconnaissance Team Report, USGS Open-File Report 2010-1048.

USGS (2010). Documentation for Initial Seismic Hazard Maps for Haiti, Open File Report 1067.

Ventura, C., Elwood, K., and Huffman, S. (2008). Preliminary Report - Wenchuan Earthquake of May 12, 2008 - Reconnaissance Trips. 
Yeats, R.S., Sieh, K. and Allen, C. R. (1997). The Geology of Earthquakes, Oxford Univ. Press.

Yin, Y., Zheng, W., Li, X., Sun, P. and Li, B. (2011). Catastrophic Landslides Associated with the M8.0 Wenchuan Earthquake, Bull. Eng. Geol. Environ. 70:15-32. 


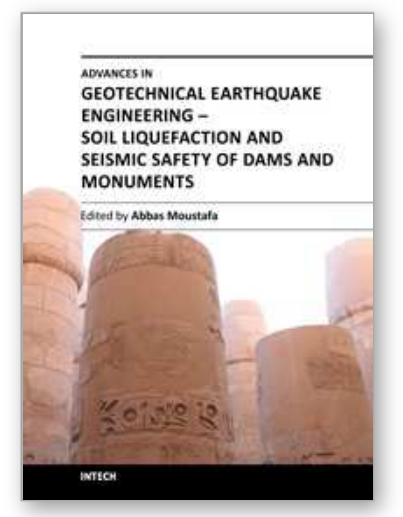

\author{
Advances in Geotechnical Earthquake Engineering - Soil \\ Liquefaction and Seismic Safety of Dams and Monuments \\ Edited by Prof. Abbas Moustafa
}

ISBN 978-953-51-0025-6

Hard cover, 424 pages

Publisher InTech

Published online 10, February, 2012

Published in print edition February, 2012

This book sheds lights on recent advances in Geotechnical Earthquake Engineering with special emphasis on soil liquefaction, soil-structure interaction, seismic safety of dams and underground monuments, mitigation strategies against landslide and fire whirlwind resulting from earthquakes and vibration of a layered rotating plant and Bryan's effect. The book contains sixteen chapters covering several interesting research topics written by researchers and experts from several countries. The research reported in this book is useful to graduate students and researchers working in the fields of structural and earthquake engineering. The book will also be of considerable help to civil engineers working on construction and repair of engineering structures, such as buildings, roads, dams and monuments.

\title{
How to reference
}

In order to correctly reference this scholarly work, feel free to copy and paste the following:

Robert C. Lo and Yumei Wang (2012). Lessons Learned from Recent Earthquakes - Geoscience and Geotechnical Perspectives, Advances in Geotechnical Earthquake Engineering - Soil Liquefaction and Seismic Safety of Dams and Monuments, Prof. Abbas Moustafa (Ed.), ISBN: 978-953-51-0025-6, InTech, Available from: http://www.intechopen.com/books/advances-in-geotechnical-earthquake-engineering-soil-liquefactionand-seismic-safety-of-dams-and-monuments/lessons-learned-from-recent-earthquakes-a-geoscience-andgeotechnical-perspective

\section{INTECH}

open science | open minds

\section{InTech Europe}

University Campus STeP Ri

Slavka Krautzeka 83/A

51000 Rijeka, Croatia

Phone: +385 (51) 770447

Fax: +385 (51) 686166

www.intechopen.com

\section{InTech China}

Unit 405, Office Block, Hotel Equatorial Shanghai

No.65, Yan An Road (West), Shanghai, 200040, China

中国上海市延安西路65号上海国际贵都大饭店办公楼 405 单元

Phone: +86-21-62489820

Fax: $+86-21-62489821$ 
(C) 2012 The Author(s). Licensee IntechOpen. This is an open access article distributed under the terms of the Creative Commons Attribution 3.0 License, which permits unrestricted use, distribution, and reproduction in any medium, provided the original work is properly cited. 